Ankara Üniversitesi Türk Inkılâp Tarihi Enstitüsü Atatürk Yolu Dergisi S 37-38, Mayı-Kasım 2006, s. 141-186

\title{
Avrupa Gazetelerinde Atatürk’ün Ölümüyle İlgili Olarak Çıkan Haber ve Yorumların Türk Basınına Yansıması
}

\author{
Yrd. Doç. Dr. Nurcan TOKSOY*
}

\section{ÖZET}

Mustafa Kemal Atatürk'ün tarih sahnesine çıkmadan önce ve çıktıktan sonra Avrupa'nın Türkiye'ye bakış açısı arasında büyük farklılıklar olmuştur. I. Dünya Savaşı yıllarında "hasta adam"ın cenaze törenini yapan Avrupa, Milli Mücadele ve sonrasında Türkiye ve Türk milletinden çok daha büyük bir saygı ile bahsetmeye başlamıştır.

M. Kemal Atatürk, 1921-1937 yılları arasında dünyanın birçok ülkesiyle dostluk anlaşmalarl yapmak suretiyle yeni kurduğu Türkiye Cumhuriyeti'ni bir barış çemberi içerisine almış ve ona güvenli bir gelecek sağlamıştır. O'nun zamanında On sekiz Avrupa ülkesinde Türk elçilikleri açılmış ve Türkiye'nin dış ilişkilerinde yeni atılımlar gerçekleşmiştir. Gerçekleştirilen bu barış̧ı çabalar tüm dünya tarafından takdirle karşılanmıştır.

Atatürk'ün dost ve düşmanlarıla kurmuş olduğu bu dostluk ilişkisi dünyada ilk ve tek örnektir. Bu nedenle ölümünden sonra dünya kamuoyunda yazılanlar ve söylenilenler de belki de başka bir lidere nasip olmamıştır. Atatürk için yazılanlar bir araya getirildiğinde O'nun büyüklüğünü daha iyi anlamak mümkün olacaktır.

Anahtar Kelimeler: Atatürk, Avrupa, Basın, Türkiye, İnklâp

The Reflections, in the Turkish Media, of the News and Comments Regarding Atatürk's Death in the European Press

\section{ABSTRACT}

There were quite differences in the point of view of European against Turkey after and before coming out Mustafa Kemal Atatürk's to the history

\footnotetext{
• Erzincan Üniversitesi Eğitim Fakültesi Sosyal Bilgiler ABD.
} 
stage. During the World War I, although the European carried out the funeral ceremony of the "patient man", in the national struggle and then, they had been talked about Turkey and Turkish more respectful than the old.

Mustafa Kemal Atatürk formed a peace hoop around The Turkish Republic founded newly providing he the friendship pacts with the thirty two countries between 1921 and 1937 provided that was a trust future to Turkey. In his time, Turkish embassies were opened in the eighteen European countries and were carried out same advances in the Turkish foreign affairs. These peace efforts have been approved of all worlds with appreciation.

The friendship relation of Atatürk between the friend and the enemy countries was the first and unique in the world. Therefore, the publications and talks about him in the world-public opinion after his death have not been done for another leader. It is possible that it could be understood when they are collected the publications about Atatürk.

Keywords: Atatürk, European, Presses, Turkey, Revolution

\section{GİRIŞ}

Atatürk, Türk Milli Mücadelesini zaferle sonuçlandırınca sömürgeci Batı telaşa kapılırken, Doğu halkları, yani Asya ve Afrika'nın mazlum milletleri Mustafa Kemal'i kahraman olarak yüceltmiş, bayraklaştırmıştır. O'nun büyük zaferi dünyada çığır açan bir zafer olmuş, ezilen halklara ilham vermiş ve sömürgeciliğin sonunu hazırlamıştır. Atatürk'ün Kasım 1938' de vefatı da aynı şekilde büyük yankı uyandırmış, bu defa dünyanın yalnız doğusu değil batısı da bu haber karşısında büyük bir yasa boğulmuştur. Kısaca O'nun tarih sahnesine çıkışı da dünyadan ayrılışı da evrensel bir olay olmuştur. Özellikle yabancılar Atatürk'ü tanımlarken O'nun için yetmiş üç sıfat kullanmışlardır' ${ }^{1}$.

Gerçekleştirdiği mücadelesiyle emperyalizme karşı koyan Atatürk, ülkesindeki bağımsızlık hareketiyle örnek alınırken, yine bağımsızlık sonrası milli devlet yaratma teşebbüsü, doğulu bir toplumu modern batılı bir millet haline getirmesindeki başarıları büyük bir dikkat ve itina ile izlenmiştir. Bütün bunları yaparken de savaş sonrası Atatürk'ten memnun olmayan Avrupa kamuoyunu inkılâpları ve barışçı çabalarıyla etkileyerek hayranlık uyandıracak dereceye getirmesi son derece önemli bir başarıdır. Atatürk, özellikle Türkiye'nin Milletler Cemiyeti'nin kararlarına uymasını, barışın ve silahsızlanmanın ihlal edildiği dünyada şartları takip ederek görüşmeler yolu ile hoşnutsuzluğunu gidermesini sağladığı gibi, II: Dünya Savaşı'na doğru giden dünyada bölgesinde barışı koruyan ve dünya barışına katkı yapan bir ülke olarak anılmasını da sağlamıştır.

1 Bu sıfatlardan bazıları; "Türkiye'nin Lideri", "islam Dünyasının Kahramanı" ,"Doğunun Kahramanı" "Evrensel Sima","Cağımızın En Büyük Adamı","Dünyanın En Büyük Devlet Adamlarından Biri", "Dünyanın En Büyük Devlet Kurucularından Biri", "Dünyanın En Büyük Simalarından Biri","Hürriyet Şampiyonu", "Dünyanın Yetiştirdiği En Büyük Reformcularından Biri"dir. Bkz. Bilal Şimşir, "Atatürk'ün Küresel Yönü Üzerine Şematik Bir Bakış", Beşinci Uluslararası Atatürk Kongresi, I, Ankara 2005, s. 135. 
Şöyle ki Atatürk, dünyanın birçok ülkesiyle dostluk anlaşmaları yapmak suretiyle yeni kurduğu Türkiye Cumhuriyeti'ni bir barış çemberi içerisine almış ve ona güvenli bir gelecek sağlamıştır. Kısaca Atatürk'ün takip ettiği bu politika, dört kıtayı dostça kucaklamak, doğusu, batısı, kuzeyi ve güneyi ile yer küresine bir bütün olarak bakmak demekti. Açıkçası Atatürk, yer küreyi bir bütün olarak kavrayıp, Türkiye'nin dış politikasını dostluk temeline oturtmak istediği için dünyada bu kadar büyük bir etki yaratmış ve bütün bu barışçıl çabaları tüm dünya tarafından büyük bir takdirle karşılanmıştır. Hatta 1920'lerde Türkiye'nin ezeli düşmanı olan Yunanistan Başbakanı E. K.Venizelos'un, Atatürk'ü 1934'de Nobel Barış Ödülü’ne aday göstermesi o dönemde ciddi anlaşmazlıklarla ayrılmış olan milletlere samimi bir barış örneği vermiştir.

Atatürk belki Nobel Barış Ödülünü alamadı ama ondan sonra gelen II. Dünya Savaşı ve dünyanın her köşesinde devam eden çatışmalar O'nun barışçı politikasının önemini ortaya koymaya kâfi gelmiştir. Hatta Atatürk'ün tüm yaşamı boyunca insanlar arasında hiçbir renk, din, ırk ayrımı gözetmeksizin bir uyum ve iş birliğinin yayılması yolundaki çabalarını dikkate alan UNESCO, 1981 yılını Atatürk yılı olarak ilan etmiştir. O'nun ölümünden sonra Avrupa gazetelerinde çıkan yazılarda, çalıştığı tüm alanlarda olağanüstü inkılâpçı olduğu belirtilmiş, özellikle sömürgecilik ve emperyalizme karşı açılan savaşların ilk lideri olduğu vurgulanmış, dünya milletleri arasında karşılıklı anlayışın ve devamlı barışın değerli öncüsü bulunduğu gerçeğine önemle işaret edilmiştir.

$\mathrm{Bu}$ çalışmada Mustafa Kemal Atatürk'ün ölümünden sonra onun kişiliğinin ve yarattığ 1 eserinin, dolayısıyla ülkesinde gerçekleştirdiği yeni yapılanmasının Avrupa devletleri tarafından nasıl değerlendirildiği ve ne şekilde algılandığ 1 üzerinde durulacaktır. Bu değerlendirmede Avrupa gazetelerinde yayınlanan haberlerin Türkiye'deki gazetelere yansıyan yönleri ele alınacaktır. Özellikle Milli Mücadele sonrasında Avrupa'nın Türkiye'ye bakış açısı ön planda yer almakla beraber, bir dünya lideri olarak Atatürk'ü nasıl değerlendirdikleri üzerinde de durulacaktır. Atatürk ile beraber dünya politikasında saygın yerini alan Türkiye ve dolayısıyla Türk milleti zedelenmiş gururu ile birlikte onurunu da kurtarmış, dünyanın diğer çağdaş toplumları arasında layık olduğu konuma kavuşmuş olması Avrupa gazetelerinde yer alan en önemli husus olmuştur.

\section{A- Ingiltere'deki Yankalar}

Atatürk henüz hayatta iken dahi O'nun ölmez eserinden ve başarılarından büyük bir övgüyle bahseden Avrupa gazeteleri ve yazarlar, $O$ öldükten sonra da aynı şekilde yazılarına devam etmişler ve Türk milletinin büyük acısını paylaşmışlardır². Atatürk'ün ölümü yalnız Türk milletinin

2 "Büyük Önderimizin Vefatı Bütün Cihana Derin Heyecan ve Teessür Verdi", Tan, 12 Kasım 1938, s. 2; İngiltere Başbakanı, Winston Churchill Atatürk için; "Hiçbir yerde zafer Türkiye ye karşı olduğu kadar tamlıkla kazanılmamıs, hiçbir yerde zafer sahiplerinin gücüne karşı Türkiye de olduğu kadar mağrurca kafa tutulmamıştır". Bkz. Cemal Avcı, "Türkiye ve 
kalbinde değil bütün dünya milletleri üzerinde derin bir tesir yaratmıştır. Atatürk'ün lehinde olmaları önceden imkânsız görülenler bile olumlu sözler söyleyerek sütunlar dolusu yazılar yazabilmişlerdir. Örneğin Times gazetesi onun için şu cümleleri kullanmıştır; "Bir zamanlar Avrupa'ya fuzuli girmiş sayılan Türkiye, Atatürk'ün sayesinde Avrupa'nın iç politikasında değerli bir üye olmuştur" ${ }^{\prime \prime}$.

Bütün Londra gazetelerinin, onun için baş makaleler ve makaleler yazdıklarını Türkiye'deki gazete haberlerinden öğrenmekteyiz. Londra'daki Observer gazetesinin Atatürk için; "Muasır hiçbir isim Atatürk adı kadar büyük saygı telkin etmemiştir. Atatürk yalnız. Türkiye'nin bütün hayatını değiştiren bir deha değil, fakat beynelmilel münasebetlerde iyilik ve yalnız iyilik yapan bir adamdır ${ }^{4}$ " ifadelerini kullandığını Ulus gazetesinin verdiği haberden öğrenmekteyiz.

Ulus gazetesinin verdiği başka bir habere göre, Sunday Times gazetesinde çıkan bir yorumda da; "İngiltere cevval, cesur bir düşman sonra da sadık bir dost olarak tanıdı ğı büyük adamı selamlamaktadır" denilerek, Türk milletinin acısını paylaştığını ve İngiliz gazetelerinin Atatürk'ün, hiçbir devlet adamının o zamana kadar yapamadığı işleri başardığını büyük bir hayranlıkla yazdıklarını bildirmiştir.

Ayrıca Sunday Times'da Herbert Sidebotham imzasıyla yayınlanan makalede, büyük lider için devlet adamlarının en cesur ve en orijinali olduğu belirtilerek; "Mustafa Kemal Atatürk, Gelibolu'da İngiliz ordusunu mağlup etmiş, Filistin'de çarpışmıs, büyük harpten sonra Yunan ordusunu yenerek gazi unvanını kazanmıştır. Fakat 1923'de cumhuriyeti ilan ettiği güne kadar bütün dünya onun asker olduğu kadar da devlet adamı olduğunu bilmiyordu. Onun bir devlet adamı görüşüne sahip olduğunu ilk gösteren emare Ankara'da yeni bir hükümet merkezi kurması olmuştur. $O$, harbin act hatıralarını ortadan kaldırmış, yalnız Türkiye için yeni bir siyasetin temelini atmakla kalmamış, fakat Ingiltere için de sağlam bir şark politikasının esasını kurmuştur... Atatürk, eskimiş ilimlerle lüzumsuz yere kafasını yormamış olduğundan dolayı daha cesur ve daha taze düşünen adamlardan birisidir... Ingiltere'ye dost olmuştur ve dost kalacaktır. Onun bir memlekete olan dostluğu ve hayranlığı, aynı siyaset müesseselerine malik olmayan milletler arasında bir dostluk teşekkül edemeyeceği hakkındaki anti tezin boşluğunu belirten bir delil diye gösterilebilir ${ }^{6}$ " denilmiştir.

Times gazetesi başmakalesinde Atatürk için; "Yeni Türkiye'nin Kurucusu ve Yapıcısı Büyük Asker, Büyük Devlet Adamı ve Büyük Şef"

Dünya için Artarak Devam Eden Önemi ile Atatürkçü Düşünce Sistemi”, Beşinci Uluslararast Atatürk Kongresi, I, Ankara 2005, s. 847.

3 "1938 Türkiyesi", Ulus, 11 Aralık 1938, s. 5.

4 "Büyük Yasımız ve Yabancı Basın”, Ulus, 14 Kasım 1938, s. 3; “Atatürk'ün Ölümü Karşısında Dünya Matbuatı”, Kurun, 15 Kasım 1938, s. 2; Ayın Tarihi, Kasım 1938, s.173.

s "Büyük Yasımız ve Yabancı Basın", Ulus, 14 Kasım 1938, s. 3.

${ }^{6}$ Yabancl Gözüyle Cumhuriyet Türkiyesi (1923-1938), İstanbul 2003, s. 79-87. 
sıfatını kullanmış ve ölümünü haber verdikten sonra O'nun gerçek hayat hikâyesinin 1919'dan itibaren başladığını ve Türkiye'nin tarihinin O'nun hayatının tarihi olduğunu; "Cesareti ve vatanperverliği onu ümitsiz görünen bir teşebbüsün başına, küçük bitkin ve muzaffer müttefiklerin kahir istekleri önünde bütünlüğ̈̈nü kaybetmiş bir milletin mukavemetinin başina koydu. Onun ruh kuvveti, azim ve iradesi kim olursa olsun diğer herhangi bir şefi sarsabilecek olan zorluklarl yenmesine yardim etti" dedikten sonra O'nun daha önce Gelibolu yarımadasındaki mücadelede İngilizlere karşı askeri dehası sayesinde milletinin talihini tersine çevirdiğini ve sonuçta kesin bir zafer kazandığını belirtmiştir. Ayrıca zafer sonrasında galip asker olmakla beraber, cesareti ve basireti sayesinde de büyük bir devlet adamı olma vasfını kazandığını da yazmıştır. Gazete, Avrupa'nın kısa zaman önce yaptığı hatayı da vurgulayarak, Türkler için "hasta adam" deyimini kullandığını ve O'nun ölümüi için ayin yaptığını, ancak büyük liderin Avrupa otoritelerini mahcup ettiğini belirtmiştir. Makalenin devamında ise;

"Türkiye sekiz sene hemen hemen kesilmeden devam eden harpten dolayı son derece ezilmişti. Yolları, ziraatı ve ticareti harap ve perişan bir durumdaydı... Türkiye'yi ziyaret eden Avrupalıların birçoğunun hilafına olarak bu cesur idealist adam güzel hayaller beslemiyordu. Avrupalı düsman ve menfaatperest devletlerin arasinda nüfuz ve kuvvetten mahrum padişahların debdebesi, ülkenin geleceğine hâkim olmak sevdası kendisine cazibedar olamamıştır. Kendisi bunların ölmüş bir imparatorluğun ve göçmüş bir âlemin bakayasından başka bir şey olmadığını görmüştü" cümleleriyle o dönemin Türkiye'sinin içinde bulunduğu durumu tasvir ederken gerek Türk çiftçisinin gerekse Türk kadınının içinde bulunduğu duruma da değinerek yapılması gerekenleri doğru tespit ettiğini vurgulamış ve Atatürk'ün Doğuya sırtını çevirerek Batıya yönelmesini ve Batının değerleriyle barışık olmasını tasvip etmiştir. Burada gazete çok önemli bir gerçeği de ifade ederek, Avrupa'nın o zamana kadar Türkleri kendilerine düşman olarak gördükleri halde ve Atatürk'ün bu bakış açısını bilmesine rağmen yine de Avrupa'ya yönelmesini büyük bir takdirle karşıladıklarını yazmıştır?.

Times gazetesi bütün bu yorumlarını yaparken objektif davranmış ve Atatürk'ün üstün özellikleri arasında özellikle insani yönü üzerinde durarak şöyle devam etmiştir; "Onun muvaffakiyetleri yalnız memleketin dâhilinde Avrupalılaşmasına münhasır kalmiyordu. Daima ilham ve bazen de idare ettiği harici politika, Türkiye'yi batı devletlerinin dostluk çerçevesi içine koydu ve eski düşmanlardan yeni dostlar yaptr. Evvelce Avrupa'da bir tüfeyli telakki edilen Türkiye, onun idaresi altında Avrupa politik hayatının klymetli ve müterakki bir azası haline geldi. Türkler için bir bahtiyarllk eseri olarak $o$, diğer millet şeflerini eski arkadaşlarını uzaklaştırmaya sevk eden şüphe ve hasetlere asla kapılmadı. Onun kurduğu sosyal ve politik akide sağlam

${ }^{7}$ Ayın Tarihi, Kasım 1938, S. 60, s. 172. 
temellere dayanmaktadır" 'Yapılan bu yorumda Atatürk'ün Avrupa'ya yönelirken doğru bir tercih yaptığı ve devletinin temellerini sağlam esaslara dayandırdığını da söylemesi olayların gidişatından duydukları memnuniyetin bir ifadesi olmuştur.

Atatürk'ün yeni bir Türkiye yaratması hususunda ise;"Türkiye, Atatürk'ün liderliği altında Avrupa'nın iç politikasının klymettar ve terakkiperver bir azası olmuştur. Türkiye'nin içtimai ve siyasi yeni binası sağlam temeller üzerine kurulmuştur. Latin harflerinin kabulü, kadınların hürriyeti, idare tarzının ıslahı, yolların, maliyenin ve ziraat usullerinin iyileştirilmesi, yeni ve insani kanunların uygulanması hepsi Atatürk'ün eseridir. Harp ve ihtilallerden doğan yeni Avrupa'nın liderlerinden hiç biri Atatürk'ün karşılaşstı̆̆ı müş̌ülatın daha büyüğüne maruz kalmamış ve ondan daha fazla hizmet göstermemiştir. Kendisi tarafından hazırlanmiş ve idare edilmiş olan Türk inkılâbı, erkek, kadın bütün vatandaşlara Türkiye'nin evvelki nesillerden hiçbirine nasip olmayan hür, tam ve emin bir hayat verdi. $O$ bir milleti, matem içinde biraktı. Türkler şimdi dostları olan ve Atatürk'ü kendisinden korkulur bir düşman sifattyla derin bir hayranlıkla takdir etmiş olan Ingilizlerin bu kadar büyük bir adamın ölümünün Türkiye ve Avrupa için hâsıl ettiği ziyadan dolayı pek ziyade müteessir olduklarını bilerek müteselli olabilirler. Kararl cesareti ve siddeti Türkiye'yi düşmandan kurtarmıs ve sonra da yalnız Rusya'da Pier ve Lenin tarafindan yapllan sosyal değişikliklerle kabili mukayese değişiklikler vücuda getirmiş olan hayret verici adam öldü..." " yorumuyla Atatürk'ün üstün özelliklerini anlattığını Ulus, Cumhuriyet, Akşam ve Tan gazetelerinin haberlerinden öğrenmekteyiz.

Tan gazetesindeki başka bir haberde ise, Times gazetesinde Atatürk hakkında yeni bir makale yayınlandığını ve bu makalede; "Asker, teşkilatçı ve idareci, onun modern Türkler arasında hiçbir rakibi yoktu ve çok eski zamanın harpçi sultanları arasında da pek az rakibi vardı. Muvaffakiyetleri Türkiye'yi bir Avrupa devleti yaptı. Yakın doğunun tarihini değiştirdi ve Müslümanlığın istihalesinde hala daha kati bir tesiri olabilir" ${ }^{10}$ yorumunun yapıldığını görmekteyiz ${ }^{11}$.

${ }^{8}$ Ayın Tarihi, Kasım 1938, s. 172; S. R. Sonyel , "Kurtuluş Savaşı Döneminde Mustafa Kemal Atatürk'ün Evrenselliği”, Üçüncü Uluslararası Atatürk Sempozyumu, I, Ankara, 1998, s. 50-51.

${ }_{9}^{9}$ Ayın Tarihi, Kasım 1938, s. 172; "Dahi Asker, Dahi Devlet ve Islahat Adamı Atatürk", Akşam, 13 Kasım 1938, s. 2; "Hariçte Duyulan Derin Teessürler", Tan, 13 Kasım 1938, s. 9; "Dünya'nın Büyük Kaybı", Cumhuriyet, 12 Kasım 1938, s. 5; Atatürk ve Cihan", Cumhuriyet, 15 Kasım 1938, s. 5; "Muzaffer Bir Kumandan Basiretli ve Uzağı Gören" Islahatçı Bir Devlet Adamı Atatürk", Ulus, 16 Kasım 1938, s. 5.

10 "Hariçte Duyulan Derin Teessürler", Tan, 13 Kasım 1938, s.9; Yabancı Gözüyle Cumhuriyet Türkiyesi, s.97-103.

"Ingiltere, Atatürk için sadece ölümünden sonra değil hayatta iken de, pek çok yazılar yazmış ve yaptıklarıyla yakından ilgilenmiştir. Örneğin Times Gazetesi, 28 Temmuz 1923 tarihli sayısında Ağa Han'ın Müslümanlara yönelik şu mesajını yayınlayarak Atatürk'ün bir ilke imza atmış olduğunu belirtmiştir; "Tarihte ilk kez Müslüman bir ulus adına, batının yüce güçleri ile kesinlikle eşitlik koşullarına dayalı bir antlaşma imzalanmamıştır. Bu antlaşma, 
İngiltere'nin Ankara Büyükelçisi Percy Loraine, Atatürk'ün ölümü üzerine 25 Kasım 1938'de, İngiltere Dışişleri Bakanı Lord Halifax'a gönderdiği yazıda Atatürk için; "Atatürk, yalnız bu veya şu savaşı kazanmak, bu yasayl veya șu alfabeyi uygulatmak, fesi yasaklamak ve devleti laikleştirmekle değil, yüzyıllar boyunca bir ulus oluşturan, ruhu kamçılayıcı idaresizlik altında inleyen bir soyun dehasına güvenmekle ve uzun süre kölelik altında kalmasına izin vermeyeceği hesapsız gü̧̧ ve yetenekleri özgürlüğe kavușturmakla, son on beș yll içinde, ölçülmesi güç iyilikler yapmıştır. Bu iyilikler onun yüceliğinin ve olağanüstü düşünün ölçüsü olmalıdır... ${ }^{12 "}$ ifadelerini kullanmıștır.

Percy Loraine ayrıca gazeteye verdiği demecinde de; "Atatürk yapılması gerektiğine inandı̆̆ını yapmaktan asla yılmadı. Hastalı̆̆ının sonucu olarak ölüme yaklaştığı sırada dahi kalbine ve aklına asla korku işlemedi. Türk halkının hizmetinde öldü. Ölüm dahi onu en büyük zaferi olan şu başarılarında asla aldatamadl. Atatürk Türk Halkına yaşam, onur, gurur, yaşam aracl ve en yüce ödül olarak tüm bunların zevkini tatma özgürlüğü să̆ladı" ${ }^{\prime 3}$ demiştir.

Bütün bu yorumlarıyla Loraine'nin, Atatürk'ü gerçek anlamda çok iyi tahlil ettiğini görmek mümkün olmaktadır. Bir Avrupalı olarak O'nun, Atatürk'ü tarafsız olarak böyle bir değerlendirmeye tabi tutmuş olması da yine büyük liderin kendi şahsiyetiyle doğrudan orantılıdır. Loraine, 3 Aralık 1938 'de İngiltere Dışişleri bakanlığına gönderdiği yazıda ise Atatürk için duyduğu özlemi şöyle ifade etmiștir; "Dramatik dinamizmi ve mıknatıs gibi çekicilï̆i ile Atatürk özlenecektir. Onun yası gerçektir. Bu özlem, cenaze törenleri sırasında halk arasında pek acı bir biçimde kendini göstermiştir ve kesinlikle gerçektir... Atatürk'ün anısına olan bağlıllk ve onun kurmuş olduğu yapının sağlamlığı, gelecek yılların ă̆ırlığı altında denenecektir. Kendi görüşünce her ikisi de bu ağırlı̆̆ı başarıyla kaldıracaktır"14. Bu cümlelerde dikkatimizi çeken bir diğer husus ise Türkiye'nin O'nun ölümünden sonra da adımlarını sağlam atacağı ve temellerin sağlam olduğu konusundaki inancı olmuştur.

Gazi Mustafa Kemal'in metin önderliği için en yüce kredidir. Türk milli devletinin sağlamış olduğu özgürlük bir bütündür".

Yine Ingiliz Yarbay A.C. Yate, The Asiatic Review dergisinin Ocak 1923 sayısında söyle diyordu; "Mustafa Kemal'in adı, kendi ilkelerini ve ulusların kurtaranlar gibi tarihe geçecektir". İngiliz yazar Elizabeth Monroe ayn fikirleri destekleyerek; "Onun yenilgiye uğratılmış bir devletin, yenen devletlere eşit koşullara göre işlem yapabileceğini, Sevr Antlaşmasını yırtarak onun yerine büsbütün değisik olan Lozan Antlasmasını kabul ettirebileceğini göstermiş olması, Arap dünyası, Mısır ve Irran'da hoşnutsuz uluslar için bir tonikti. Bu gelişmelerden sonra, bu uluslar, uzun yıllar bu başarıyı düşünürken zevk duyuyorlardl" demistir. $50-51$.

Bkz. Sonyel , "Kurtuluş Savaşı Döneminde Mustafa Kemal Atatürk'ün Evrenselliği”, s.

${ }^{12}$ S. R. Sonyel, a.g.m, s. 50-51. 24-25.

${ }^{13}$ S. R. Sonyel , "Yabancı Gözü ile Atatürk”, Türk Kültürü, IX, No. 91, Kasım 1970, s.

${ }^{14}$ S. R. Sonyel , "Büyük General, Asil Düşman ve Cömert Dost Gazi Mustafa Kemal”, Belleten, XLIII, No.171, Temmuz 1979, s. 75. 
Daily Telegraph gazetesi, "Modern Türkiye'nin Yaratıcısı" başlığı altında yayınladığı başmakalesinde Atatürk için; "Devrimiz, ne lüzumlu varlıkların ve iktidarların uğradığı süratli değişikliklere şahit olmuş ve birçok kuvvetli adamların ansızın otokratllğa yükseldiklerini görmüş̧ür. Tarih bu adamların başarılarını araştırdı ̆̆ı zaman, Atatürk'ten başkasının bir milleti ve devleti yeniden kurmak hususunda daha hayret verici, daha iyi ilhaml bir şekilde hareket etmediğine karar verebilir. Ziraatla derinden alakadar olan Atatürk, yeni Türkiye'yi ziraata bağladı. Ziraat metotlarının ıslahını, çiftçilerin korunmasını temin etti. Memleket endüstrisini kurmak için geniş projeler hazırlanmış ve memleket kaynaklarl geniş ölçüde işletilmiştir. Hepsinden daha önemlisi Kemal Atatürk'ün milli enerjiyi canlandırması, sosyal hayatı hızlı bir şekilde değiştirmek gibi Türkiye'ye mazi gözüyle bakanların imkânsız saydıkları işi başarmasıdır. Büyük Petro, Rusya'yı bu derece değiştirmeği aklından geçirmemişti. Şer'i mahkemeler kaldırllarak yerlerini medeni kanuna birakmış, Avrupai giyim kabul olunmuştur. Hepsinden daha çok hayret vereni kadın hürriyetinin teminidir. Kadınlar başka hiçbir memlekette bu kadar süratle ilerlememişlerdir. Bir milletin bu derece değişmesi tarihte hakikaten eşi olmayan bir hadisedir"'/5 yorumunu yaparak O'na tarih sayfalarında önemli bir yer ayırırken, inkılâplarını ön plana çıkardığını Ulus gazetesinden öğrenmekteyiz.

Ulus Gazetesi, Daily Telegraph gazetesinde yer alan bir başka yoruma bağlı olarak verdiği haberinde Atatürk'ün liderlik vasfıyla ilgili olarak; "Müteaddit kuvvetli adamların iktidar mevkiine geldiğini gören neslimiz. bunların eserlerini gözden geçirdiği vakit hiçbir millet ve devlet inkılâbının ne Atatürk tarafindan yapilan kadar fevkalade ne de onun kadar iyi mülhem olmadı̆̆ını anlayacaktır" ${ }^{\prime 16}$ sözlerine yer vermiştir.

News Chronicle gazetesi ise, "Bozkurt" başlı̆̆1 altında yazdığ makalesinde; "Atatürk eğer yaşasaydl tarihin bugünkünden çok farklı olacağını, bir hakikat olarak söyleyebileceğimiz mahdut adamlardan birisiydi. Hiçbir diktatörün başaramadığl muvaffakiyetleri Atatürk başard" "' diyerek O'nun tarihin akışına yön verebilecek kadar büyük bir değer olduğunu vurgulamıştır.

Yine aynı gazetenin Charles Vernon Bartlett'in imzasını taşıyan bir makalesine dair verdiği haberinde Kurun ve Akşam gazeteleri büyük lider için şu ifadelere yer vermiştir; "Atatürk'ün sslahatı devamlı olacaktır. Zira bu ıslahat harpten evvel kendisini tanımış olanlar için hemen hemen tanınmayacak derecede değişmiş olan Türkiye'de Türk milletini kurtarmıştır. Atatürk Türkiye'yi inhitat etmiş bir memleket halinden kuvvetli ve hürmet

15 "Modern Türkiye'nin Yaratıcısı", Ulus, 16 Kasım 1938, s. 5; Ayın Tarihi, Kasım 1938 , s. 173

16 “Atatürk Karşısında Dünya'nın Dili”, Kurun, 13 Kasım 1938, s. 3

17" "Dahi Asker, Dahi Devlet ve Islahat Adamı Atatürk", Akşam, 13 Kasım 1938, s. 2; "Hariçte Duyulan Derin Teessürler", Tan, 13 Kasım 1938, s. 9. 
edilen bir memleket haline çevirmiş ve onu tek düşmanı kalmadan bırakmıştır. Bu, zamanımızın hiçbir diktatörünün başaramadığı bir şeydir"18.

Yine; Kurun, Akşam ve Tan gazeteleri Daily Mail gazetesindeki bir makaleye dair verdikleri haberlerinde, o günkü Türkiye'nin durumundaki gelişmelerden bahsederken şu satırlara yer vermişlerdir; "Bugün Türkiye büyük ve yeni bir memlekettir. Harp sonrasının dehşet ve bitkinliğinden çıkmış olan bu yeni Türkiye Atatürk'ün dimağında vücut bulmuştur. $O$, bu Türkiye'yi kendi elleriyle dünyaya getirdi" "19. Böylece Atatürk'ten günlerce bahseden İngiliz gazeteleri O'nun dehasını, yenilmez kişiliğini, büyüklüğünü ve ileri görüşlülüğünü resmen kabul etmiş oluyorlardı. O'nun dünya barışına yaptığı katkıyı hürmetle anarken yeni bir Türkiye yaratmak için verdiği mücadeleyi de büyük bir saygı ile kabul etmişlerdir.

Daily Express gazetesi de, Atatürk'ün Türkiye'yi hesaba katılması gereken yeni bir memleket haline getirmesinden bahsederek önemli bir gerçeği vurgularken Daily Herald ise O'nun hayatını uzun uzun anlatmakla yetinmiştir ${ }^{20}$.

J.H.Waltun, Daily Telegraph gazetesine yazdığ 1 makalede; "Cumhuriyet Türkiye'si, toprak ihtiras ve anlaşmazlı̆̆ sonu sinırlarından memnun olan birkaç memleket arasındadır" ${ }^{2 l}$ derken, Türkiye'nin entrika ve hilelerden arınmış olduğunu Atatürk'ün sayesinde "hasta adam" unvanından kurtulduğunu da vurgulamak istemiştir22.

1935-1938 İngiliz Büyükelçiliği yıllık raporlarında da Atatürk için özel bir yer ayrılmış ve 10 Kasım'da oldukça genç yaşta vefat eden büyük liderin ölümü duyurulmuştur. Hatta Atatürk'ün değerini, karakterini ve başarılarını anlatmak için yıllık raporun uygun bir yer olmadığı belirtilmişse de yine de O'nun hakkında kısa da olsa bilgi vermeden geçememişlerdir. Yıllık raporda O'nun için şu satırlar yer almıştır; "Asker, devlet adamı ve reformcu olarak

18 “Atatürk Karşısında Dünya'nın Dili”, Kurun, 13 Kasım 1938, s. 3; "Dahi Asker, Dahi Devlet ve Islahat Adamı Atatürk", Akşam, 13 Kasım 1938, s. 2; Ayın Tarihi, Kasım 1938, s. 173.

19 “Atatürk Karşısında Dünya'nın Dili”, Kurun, 13 Kasım 1938, s. 3; "Dahi Asker, Dahi Devlet ve Islahat Adamı Atatürk", Akşam, 13 Kasım 1938, s. 2; "Hariçte Duyulan Derin Teessürler", Tan, 13 Kasım 1938, s. 9; Ayın Tarihi, Kasım 1938, s. 173.

20 "Dahi Asker, Dahi Devlet ve Islahat Adamı Atatürk", Aksam, 13 Kasım 1938, s. 2; "Hariçte Duyulan Derin Teessürler", Tan, 13 Kasım 1938, s. 9.

${ }^{21}$ Yabancı Gözüyle Cumhuriyet Türkiyesi, s. 190.

${ }^{22}$ Rom Landau bu hususla ilgili olarak 25 Haziran 1937'de The Spectator Mecmuasındaki yorumunda Atatürk'ün hasta adam kimliğinden kurtulmak için yaptıklarını şöyle anlatmaktadır; "Atatürk 'ün memleketi için neler yapmıs olduğunu tam manasıyla görebilmek ve anlayabilmek için Türkiye'yi ziyaret etmek şarttır... Türkiye inkılâbı çok daha yenidir, bu inkılâbı geçiren memleket çok daha geri çok daha karışık ve disiplinsizdi buna rağmen Kemal'in kurduğu inkılâbın semereleri bu kadar kısa bir zaman için de olsa dahi mazeret göstermek lüzumunu hissetmeyecek kadar bariz ve kâfidir. Atatürk 'ün başarıları Italyan ve Alman liderlerininkinden çok daha yüksektir... Atatürk'ün müstakil ve mütecanis bir Türkiye yaratması hic süphesiz tarihi bir bașarldır. Fakat bundan daha mühim olan bir hakikat vardır ki o da Atatürk'ün Türk milletine yeni bir ruh aşılamıs olmasıdır". Bkz. Yabancı Gözüyle Cumhuriyet Türkiyesi, s. 104-105. 
Türkiye bugün bulunduğu noktaya Atatürk gibi önemli bir liderin 15 yılllk bir yönetimi altında gelmiştir.,"23

\section{B-Fransa'daki Akisler}

Atatürk'ün ölümü İngiltere'de olduğu gibi Fransa gazetelerinde de önemli bir etki yaratmıştır. Özellikle O'nun laiklik yönü üzerinde durarak barışçı çabalarını ön plana çıkarmışlardır. Fransa'da yayınlanan Mond $e$ Vuayaji mecmuası, "1938 Türkiyesi" adlı makalesinde Türkiye'yi daima mistik bir gözle görmüş ve göstermiş olan Avrupalıların bu inanışına karşı o günkü Türkiye'nin vurduğu darbeyi anlatmaya çalışmıştır. Yazıda bu husus şu şekilde ifade edilmektedir; “...Türkiye şarklılık damgasından tamamen kurtulmuştur. Türkiye'de artık ne sarık, ne fes, ne de şalvar vardır. Kadınlar artık bize hayalet değildir. Türk kadınları sokaklarda serbest ve açık olarak dolaşmaktadırlar. Giyimleri tıpkı Paris ve Roma kadınları gibidir... Bu değismeler bütün Türkiye'nin de ğismesinin bir emsalidir. Bu icraatlarından dolayı Atatürk, Türklerin babası adını aldı ve yine bunun içindir ki, eski şark tarihinin derinliklerine Etilere kadar giderek milletinin asıl unvanların aradl. Bu gün Türkiye nüfusunun hemen hepsi Türklerden müteșekkildir ve Türkçe konuşulur. Türkiye bu mütecanis halkıyla vaktiyle ki geniș ve gayri mütecanis Osmanlı İmparatorluğu'ndan çok daha kuvvetlidir. Cünkü şimdi Türkiye'de kuvvetli bir milli irade vardır" ${ }^{\prime 2}$... dedikten sonra Türkiye'nin ekonomi alanında kat ettiği mesafeye de değinerek kısa zaman sonra Türkiye'nin bir endüstri memleketi olacağını, servet kaynaklarını daha fazla işleteceğini ve sonuçta Türk halkının tamamen refaha kavuşacağını da vurgulamıştır. Bütün bu açıklamalarda Fransa'nın üzerinde durduğu husus, Türk milletinin artık bundan sonra tamamen modern bir devlete sahip olmasidır.

Paris Soir gazetesi de öncelikli olarak O'nun inkılâpları hakkında değerlendirmede bulunmuş ve şöyle yazmıștır; “... Muzaffer bir general olan Türklerin babası yeni Türkiye'yi yarattı, sultanları kovdu, kadınlara hürriyet verdi, fesi kaldırdl ve memleketinde radikal bir değişiklik yaptı"

${ }^{23}$ Mustafa Yılmaz, "İngiliz Büyükelçiliği Yıllık Raporlarında Türkiye(1935-1938)", Beşinci Uluslararası Atatürk Kongresi, I, Ankara 2005, s. 646; Dünya radyoları da yine Atatürk için özel yayınlar yapmışlar ve; "Dünya Büyük Bir Devlet Adamını Kaybetti" ifadesini kullanmıslardır. Londra Radyosu Atatürk'ün ölüm haberini verdikten sonra șu sözleri söylemiștir; "Türkiye Atatürk'ü kaybetmekle bugünkü refah ve nüfuzunu temin eden yüksek dirayetli, uzak görüslü șefini ve dünya büyük bir devlet adamını kaybetmiştir" Bkz. "Dünya Radyoları Atatürk Için Neşriyat Yaptılar", Tan, 11 Kasım 1938, s. 2; Aynı şekilde Paris, Berlin ve Roma Radyoları da ölüm haberini verirken Türk milletinin büyük acısını paylaşmışlardır. Atatürk ölümünden çok daha sonra da dünyada gerek bilim ve düşünce çevreleri gerekse politika ve devlet adamları tarafından büyük bir ilgi odağı olmaya devam etmiştir. Sürekli olarak O'nun fikir ve düşünceleriyle ilgilenilmiş ve örnek alınmıştır. Örneğin Lord Kinross, Atatürk hakkında özel incelemeler yapmış ve bir kitap yazmıştır. Kitabında O'nun hiçbir zaman kendisini düșünmeyen, bütün varlığını yurduna ve ileri insanlık idealine vakfeden kişi olduğundan bahsetmiştir. Bkz. Abdullah İlgazi, "Dün Bugün ve Gelecekte ki Yansımalarıyla Atatürk'ün İnsan Haklarına Verdiği Değer”, 4. Uluslararası Atatürk Kongresi, I, s. 427.

24 “1938 Türkiyesi", Ulus, 11 Aralık 1938, s. 5. 
dedikten sonra Ulus gazetesi verdiği haberinde Fransız İçişleri Bakanı Albert Sarraut'un O'nunla ilgili bir hatırasını da eklemiştir ${ }^{25}$.

Albert Sarraut'un aynı gazeteye Atatürk'ün ölümü dolayısıyla yazdığı bir diğer makaleye dair Akșam, Tan ve Ulus gazetelerinin verdiği haberlere göre; “Atatürk'ün ölümü herkeste hayranllk uyandıran Türkiye için azim bir ziyadır. Onun kahramanlığ ve dehası o memleketin istiklalini yaratmış ve kalkınmasını temin etmişti. Bu ziya Fransa için de çok acıklıdır. Çünkü Atatürk onun sadık ve samimi bir dostu idi. Bu ziya sulh havası için de çok elimdir. Zira bu büyük devlet sefi yorulmaz bir surette bu davanın korunmasına çalıșmaktaydı. Bu ölüm şahsen beni de fevkalade müteessir etmiştir" diyerek Atatürk'ün başlattığı barış politikasının ölümüyle beraber sonuçsuz kalacağı endişesi dile getirilmiştir.

Albert Sarraut makalesinin devamında, Atatürk ile arasındaki duygusal bağlılığa dair; "Ankara'da elçi bulunduğum günlerde, o zaman adı Gazi Mustafa Kemal olan o büyük zatla sık sık temas imkânını bulmuştum. Aramızda samimi ve kalbi bir sevgi hâsıl olmuştu. Ona karşı hayranlık ve sevgi besliyordum. Türkiye'de bulunan bütün dostlarım, Türk milletinin en büyük matem gününde duyduğum ıstırabın ne kadar geniş olduğunu takdir ederler" ${ }^{26}$ diyerek bir Fransız siyaset adamı olarak böylesine büyük bir liderin büyüklüğünü dehasını kabul etmiş olması ve bunu dile getirmesi önemlidir. Sarraut, aynı zamanda Türk basınına da aynı tarzda beyanatta bulunmuş ve Türk milletine özel taziyesini sunmuştur ${ }^{27}$.

Jean Laubespin ${ }^{28}$ in, Atatürk hakkında yazdığ 1 makaleye dair Ulus gazetesinin verdiği bir haberde, Atatürk için söylediklerine yer vermiș ve değişik bir bakış açısıyla şöyle değerlendirmiştir; "Bütün bir milletin Atatürk adıyla andı ̆̆ adam, harikulade bir adamdl. Onda her şey tezatla doluydu. Insan onunla tanıştıktan sonra ilk zamanlar, şahsiyetinden intişar eden miknatısiyetin tesiri altında kallyor. Sonradan zarif giyinișine, kibar tavirlarına ve ince fikirlerine dikkat edebiliyordu. Etrafinı hayrete düşürmekten hoşlanan bu adam tabiatın lütfuna mazhar olmuştu. Çünkü onda her şey hakikaten insanı hayrete düşürüyordu. Onun çatık alnında ve iradesini gösteren ăgzında mavi gözlerinin bir tek baklşının derin bir tatlllık uyandırdığınt, hiç beklemediğimiz bir anda görüyordunuz. Her hangi bir ziyaretçi tam onun meziyetlerini methettiği sırada, o dudaklarında esrarlı bir

${ }^{25}$ Sarraut hatırasını şöyle anlatmaktadır: "Atatürk geçenlerde, sefirlerimizden biriyle konuşurken şöyle diyordu: Biliyor musunuz? Ben hakikaten, "ihtilalci" telakki olunacak ilk hareketi Paris'te yaptım. Bu hareket ne idi ekselans? Paris'e gelir gelmez ilk işim fesimi cıkararak sizin demokratik mölon sapkanızı giymek olmustu. Kemal Atatürk'ün çehresi mermer gibi sakin dururken, gözleri alaycl parıltılarla yanıyordu. Filhakika fesin ortadan kalkması büyük bir inkılâbın sembolünü teşkil etmiştir...". Bkz ."Atatürk, Albert Sarraut", Ulus, 15 Kasim 1938, s. 5.

26 "Atatürk'ün Ölümü Her Tarafta Derin Bir Teessür Uyandırdı", Akşam, 11 Kasım 1938, s. 2; "Hariçte Duyulan Derin Teessürler", Tan, 13 Kasım 1938, s. 9; "Atatürk, Albert Sarraut", Ulus, 15 Kasim 1938, s. 5.

27 "Milli Matemimiz ve Cihan", Cumhuriyet, 12 Kasım 1938, s. 3.

${ }^{28}$ Fransiz gazeteci. 
gülümseyişle daima aynı seyi söylüyordu. Ben on yaşından beri inkılâpçıydım. O zamandan beri hiç değişmedim. Gene sik sik tekrarlarından hoşlandığ bir cümle de şu idi. On yaşında iken Selanik'in en yaramaz ६̧осй̆ da ben idim. Fakat onun hayatın yazanlar, aynı fikirde değillerdir. Hepsi, onun daha küçük yaşta iken harikulade bir çocuk olduğunda müttefiktirler..."29.

Fransa'nın eski Ankara Büyükelçisi Kont de Chambrun, aynı gazetede yazdığı makalede, Atatürk'ün büyük bir medeniyet eseri meydana getirdiği ve el koyduğu her şeyde tamamılla başarılı olduğundan bahsetmiştir. Figaro gazetesine yazmış olduğu makalesini ise Kurun ve Ulus gazetelerinin haberlerinde görmekteyiz. Kont de Chambrun burada da Atatürk için; “Avrupa'nın karışık âleminde en önemli rolï oynayanlardan birini kader yere sermiştir. Mustafa Kemal, fakirliği, şeref ve zaferi tanımış, ananeleri yıkmıs ve dağınık bir imparatorluğun harabeleri üstünde milli bir devlet olan Türkiye Cumhuriyeti'ni kurmuştur. Bu akşam bu satırlarl yazarken, beş sene müddetle bana karşı göstermiş olduğu hayırhah dostluğu, Fransa'ya karşı dürüstlüğünü düşünüyorum" dedikten sonra büyük liderin tevazu yönüne vurgu yaparken aynı zamanda olayları değerlendirmedeki ustalığını da dile getirmiştir. Ona göre Atatürk çok farklı yeteneklere sahip bir insan, hoş sohbet, etkileyici, insanları ikna edici, fikirlerinde idealist, hayallerinin, onlara çizdiği hudutları aşmasına müsaade etmeyen karaktere sahip bir kişiydi. Hatta O'nun karakterinin en dikkate değer noktasının bu husus olduğunu söyleyerek; " $O$, emelleri tehdit etmeye muktedirdi" ifadelerini de kullanmıştır ${ }^{30}$.

Kont de Chambrun, bir başka yazısında da Atatürk'ten, “Türklerin Babası" olarak bahsederek O'nun bu ismi savaşlardaki başarıları ve barış̧̧ı çabaları ve uygarlaştırıcı adımlarıyla hak etmiş olduğunu söyledikten sonra; “... Kuşkusuz tahta çıkabilirdi, sağduyusu ve akılcılı̆̆ı onu bundan uzak tutmuş, milletin babası olmayı tercih etmişti. Kasılmadan, övünmeden şatafata kapılmadan düşünür niteliğini korumuş ve itibarı artmaya devam etmiştir" ${ }^{31}$ cümleleriyle insan Atatürk üzerinde durmuş ve bu ifadelerini hayranlıkla dile getirmiştir.

Fransa'daki Le Journal gazetesinde yayınlanan bir yazıya dair Kurun gazetesi verdiği haberinde, Atatürk'ün ölümüyle zamanın en büyük adamlarından birini kaybettiklerini, fakat ondan geriye kalan bağımsız ve müstakil Türkiye'nin, kuvvetli ve modern bir ordunun Türk milleti için en büyük bir güvence olduğunu vurgulamıştı ${ }^{32}$. Yine aynı gazete, Atatürk'ün bütün mesaisinin yapıcı olduğunu ve yapılan şeylerin devam edeceğini ve

29 “Kemal Atatürk'ün Harikulade Hayatı”, Ulus, 15 Kasım 1938, s. 5.

30 "Fransız Basını", Kurun, 14 Kasım 1938, s. 4; "Kont de Chambrun'un Bir Yazısı", Ulus, 16 Kasım 1938, s. 5; Ayın Tarihi, Kasım 1938, s. 175.

${ }^{31}$ Turhan Baycu, "Yabancı Gözüyle Atatürk", Atatürk Araştırma Merkezi Dergisi, III, Mart 1987, S. 8, s. 394.

32 "Fransız Basını", Kurun, 14 Kasım 1938, s. 4. 
O'nun eserinin daima baki kalacağını yazarak ${ }^{33}$, Ankara'da imzalanan TürkFransız Antlaşmasını da hatırlattıktan sonra, Atatürk için normalin üstündeki büyük adamlardan biri olarak bahsetmiştir ${ }^{34}$. Eski Fransa Başbakanı Mösyö Heryo ise, Atatürk'ü yakından tanımıș olmanın mutluluğu içerisinde O'nun için, büyük bir kumandan, büyük devlet adamı olarak bahsetmiş olduğunu Kurun gazetesinin verdiği haberden öğrenmekteyiz ${ }^{35}$.

Saint-Brice, aynı gazetede onun için; “Atatürk'ün bütün yapıcı eseri, çalışmaya, kitlelerin disiplinine ve gayretteki devam hassasına imtina ediyor. Türkiye'nin maddi terakkileri, cidden mahirane teşebbüslerle dolu bir harici politikanın neticesidir... ${ }^{36}$ "demiştir.

Petit Journal gazetesinde, Schacre'de ölüm haberiyle birlikte TürkFransız ilişkileri ve Türk dış politikasında her hangi bir değişiklik olmayacağı ile ilgili yazılar yazdığını yine Yeni Sabah gazetesinden öğrenmekteyiz.

Paris'in Temps gazetesi ise; "Atatürk bir milleti birkaç yılda asrileştirmek mucizesini yaratmıştır", ${ }^{37}$ yorumunu yaptıktan sonra Tan gazetesinin verdiği habere göre şöyle devam etmektedir; "Yeni Türkiye'nin yapıcısı ölmüstür. Bütün bir millet șimdi vatanının halaskarına ve memleketi baştanbaşa değiştiren inkılâpların amili muhterem büyük şefi için ağllyor. Ölüm mağlubiyet nedir bilmeyen bu adamı mağlup etmiştir. Fakat onun muazzam eseri bakidir ve Türkiye Cumhuriyeti'nin mazisi istikbal için bir kaptandır. Balkan Antantı'nın lideri ve Şark paktının yaratıcısı olan Türkiye, dünyada kendi mevkisini almıştır" ${ }^{\prime 38}$. Genel olarak Atatürk'ü değerlendirirken, O'nun ülkesine yaptığı hizmetten ve Türkiye'nin geleceğini kurtarmış olduğundan bahsetmektedirler.

Intronsigeant gazetesi de ölüm haberiyle beraber büyük liderin hayatına geniş yer ayırmış ve Marcel Sauvage'nin ${ }^{39}$ "Atatürk'ü Nasıl Tanıdım” başlığı altında bir röportajını yayınlamış ve bu röportajı Akşam gazetesi aynen vermiştir. Buna göre, Marcel Sauvage, Atatürk için; “Atatürk'ün şahsında yalnız etraflarında hayat ve ölüm mistiği yaratmaya kadir seflere has manyetizma vardır" diyerek Atatürk'ün kendisine söylediği şu cümleyi asla

33 “Atatürk'ün Ölümü Her Tarafta Derin Bir Teessür Uyandırdı”, Akşam, 11 Kasım 1938, s. 2 .

“Ulu Önderimizin Vefatı Bütün Cihana Derin Bir Heyecan ve Teessür Verdi", Tan, 12 Kasım 1938, s. 9.

${ }_{35}$ İstanbul'a gelerek Atatürk ile bizzat görüşen Heryo, onun siyasilere mahsus yüksek meziyetine yakından şahit olup ve takdir edebilmiş ve bu takdirini de ülkesine geri döndükten sonra Vişi şehrinde verdiği genel bir konferansta defalarca dile getirmiștir. Bkz. "Atatürk'ün Portresi", Kurun, 11 Kasim 1938, s. 9.

36 "Ulu Önderimizin Vefatı Bütün Cihana Derin Bir Heyecan ve Teessür Verdi”, Tan, 12 Kasım 1938, s. 9; "Kurtarıcıya En Büyük Bir Şükran Delili”, Ulus, 17 Kasım 1938, s. 5

37 "Atatürk Hakkında Dünya Matbuatı Neler Yazmıştı", Yeni Sabah, 10 Kasım 1953, s. 3; Ayın Tarihi, Kasım 1938, s. 174.

38 "Ulu Önderimizin Vefatı Bütün Cihana Derin Bir Heyecan ve Teessür Verdi”, Tan, 12 Kasım 1938, s. 9; Ayın Tarihi, Kasım 1938, s. 173-174.

${ }^{39}$ Fransiz Gazeteci. 
unutmadığını söylemiştir; "Çok büyük milletlere ait küçük memleketler vardır. Istikbal öteki milletlerden ziyade bu milletlere aittir. Bu cümleler ölümünün arifesinde yakın doğunun ve hatta bütün doğunun en şuurlu, en uyanık ve en emin adamı olarak ortaya çıkan Atatürk'ün harikalarla dolu hayatının derin manasını göstermesi açısından önemlidir",40 diyen Marcel, Atatürk'ün şöhretinin memleketten memlekete geçerek hayatının efsanevi denebilecek bir mahiyet aldığını da vurgulamıştır.

Aynı şekilde, Akşam gazetesinin verdiği habere göre Matin gazetesinin de Mustafa Kemal Atatürk için; "Mustafa Kemal banisi olduğu Türkiye Cumhuriyeti'nde hiçbir zaman Çarların bile malik olamadıkları hudutsuz kuvvet ve salahiyete sahipti. Bu derece derinden sevdiği memleketinin modern inkişafina engel olan asırlik ananeleri ve dini adetleri yıkmak için bir tek imzası kâfi gelmişti... Zira Atatürk, hakikaten zamanımızın objektif zihniyetli ve temkinli büyük adamlarından birisiydi" ${ }^{41}$ yorumunu yaptığını görmekteyiz.

Ayrica Jour Echo de Paris ${ }^{42}$, Journal, Petit Journal de Excelsior gazetelerinin de Atatürk'ün hayatı hakkında uzun makaleler yayınlamış ${ }^{43}$ olduklarını yine Türk gazetelerinden bilmekteyiz.

Petit Parisien gazetesi ise, bütün Türkiye'de büyük bir matem hüküm sürdüğünden bahisle büyük devlet reisinin şahsiyetinin çok yüksek olduğunu ve hiç kimsenin O'nun kadar halkının kalbine yakın olmadığını yazmıştır ${ }^{44}$. Ayrıca Journal de Jönev Gazetesinde de Prof. Öjen Pittar, Atatürk hakkında büyük övgülerle dolu bir makale yayınlamıştır ${ }^{45}$.

Albert Kammerer, Excelsior gazetesinde, Mustafa Kemal için; "Atatürk çok büyük bir adam ve politik bir dehadır. Memleketine en büyük hizmetleri

${ }^{40}$ Ayın Tarihi, Kasım 1938, s. 174; "Her taraftan Büyük Matemimize İștirak Ediliyor", Akşam, 12 Kasım 1938, s. 2.

4l،"Her taraftan Büyük Matemimize İştirak Ediliyor”, Akşam, 12 Kasım 1938, s. 2; Ayın Tarihi, Kasım 1938, s. 174

${ }_{42}$ Courson, Jour Echo de Paris gazetesine verdiği demecinde Atatürk için şunları söylemiştir: "Bu karışıklıklarla dolu zamanımızda belki Atatürk'ün şöhreti kadar büyük söhretler vardır. Fakat hiçbir zaman bir tek muvaffakiyetsizlik bile kaydetmemiş yegâne şöhret onun şöhretidir". Bkz. "Ulu Önderimizin Vefatı Bütün Cihana Derin Bir Heyecan ve Teessür Verdi”, Tan, 12 Kasım 1938, s. 9; “Atatürk Karşısında Dünya'nın Dili”, Kurun, 13 Kasım 1938, s. 3; "Büyük Yasımıza İstirak Edenler”, Ulus, 15 Kasım 1938, s. 5.

43 "Her taraftan Büyük Matemimize İştirak Ediliyor", Akşam, 12 Kasım 1938, s. 2; Ayın Tarihi, Kasım 1938, s. 174.

44 “Atatürk Karşısında Dünya'nın Dili”, Kurun, 13 Kasım 1938, s. 3; Ayın Tarihi, Kasim 1938, s. 173.

${ }^{45}$ Prof. Öjen Pittar, 1928'de ilk defa Ankara'ya geldiğinde, Atatürk ile tanışmış ve kendisinden çok etkilenmiştir. Atatürk, bir tarihçi olması hasebiyle, onun bilgilerinden faydalanmak istemiştir. Özellikle Anadolu'nun tarih öncesi devirleri ve Türk ırkının ve Türk medeniyetinin menşei hakkında kendisiyle uzun sohbetlerde bulunmuştur. Prof. Öjen Pittar, bu sohbetler sırasında Atatürk'ün fikirlerinden oldukça etkilenmiştir. Bkz. "Atatürk Hakkında Bazı Şahsi Hatıralar”, Ulus, 5 Aralık 1938, s. 5. 
yapmıştır..." öğrenmekteyiz.

Maurice Pernot $^{47}$ ise O'nun hakkında oldukça uzun bir makale yazmıştır. Cumhuriyet gazetesinde de yayınlanan makalesinde o; "Ĕger hakikaten Emili adı verilmeye laylk siyasi bir ihtilal varsa, o da 1919-1920 Türk ihtilalidir. 19 Mayısta Samsun'a ayak basan adam için olduğu kadar onun arkasında toplanan millet için de o tarihte bir tek sual mevcuttu. Yarın yeni bir Türkiye'nin yaşaması için ne yapmak lazım. İhtilal hareketinin ilk aşaması yabancı istilası altında kalan toprakların müdafaası ve kurtarılması olmuştur. Mustafa Kemal bunun için Türklerin yurt severlik duygularına, askeri meziyetlerine, gururlarına müracaat etmekle, onlardan beklediğ $i$ bütün fedakârlıklarl ve gayretleri temin etmiş oldu. Zafer elde edildikten sonra da Türkiye'yi kurtaran adamın memleketi nasıl işlerse öğle idare etmek hakkına sahip olduğunu inkâr eden bulunmadl. Mustafa Kemal, Türkiye'ye cumhuriyet șeklini verdi... O, devleti demokratik bir devlet olarak yarattı. Nihayet Türkiye'yi modern bir devlet yani garp organizasyon şekillerini kendi ihtiyaçlarına uydurmaya muktedir bir devlet haline getirmek istedi. 1923'de Mustafa Kemal'in bana söylediği sözleri maksadının Avrupa'yı taklit etmek değil onun terakki vasitalarından istifade etmek ve icabında, kendisini ona karşı müdafaa etmek için ondan silah almak olduğunu izah edişini şimdi yine işitir gibi oluyorum... Bütün zaferlerden sonra gazi kendisine minnettar kalan millete arzularını kolayca kabul ettirebilmişti. Fakat Atatürk'ün kendisine has dehasının tezahür ettiğ $i$ nokta, milletin gayret ve faaliyetini tehlike geçtikten sonra da idame etmek hareket zevkini muhafaza eğleme ve bu yeni vecibelerin her birine mukavemet edilemez bir cazibe vermek hususunda kullandı ̆̆ vasitalardır. Bu cihetin mantıkla izahına imkân yoktur. Bu onun şahsi sirrıdır. Atatürk insan olarak mütehakkimdir. Fakat şiddet taraflısı değildir. O, iktidar mevkiinin realitelerini sever görünüşünden ve boş sözlerden hoșlanmazdı" 48 diyerek gerçekten tarafsız bir gözle değerlendirmeye çalışmış ve bunu yaparken de O'na olan hayranlığını gizlememiştir.

Ünlü devlet adamı ve yazarı Edouard Herriot ise Fransa Başbakanı olarak 1933'de İstanbul'a geldiğinde, Atatürk ile görüşmüş ve O'nu yakından tanımak fırsatını yakalamıştır. Herriot, Atatürk'ü büyük bir barış mimarı ve yüzyılın en büyük devlet adamı olarak dünyaya örnek olduğunu söylemiştir. Atatürk'ün özelliklerini "Orient" adlı eserinde şöyle tarif etmektedir; "Atatürk'e yaklaşmış ve görüşmüş olanlar, onun bakışının gücünü, söylediklerinin doğruluğunu, kişiliğinden doğan enerjiyi, bilgisinin zenginliğini, evrende çok az örneği olan bir şahsiyetle karşı karşıya olduğunu hemen anlar... Mustafa Kemal Doğu Avrupa'da yükselen bir uygarlık abidesidir. Gerçek devlet adamı sıfatı yalnız ona verilebilir. O bir 175

46 "Atatürk ve Avrupa”, Cumhuriyet, 20 Kasım 1938, s. 8; Ayın Tarihi, Kasım 1938, s.

${ }^{47}$ Fransiz Gazeteci.

48 "Atatürk ve Avrupa", Cumhuriyet, 20 Kasım 1938, s. 8. 
barış adamıdır... Ülkesinin gerçek sahibi olarak tanımladığı köylüyü yüceltmekle kalmadı, ona bilgi, insanlık, Türklük şerefi kazandırdı. Artık hasta adam yoktu, onun yerine genç, dinamik, Türkiye Cumhuriyeti vardl" ${ }^{49}$.

Le İllustration mecmuas ${ }^{50}$ Atatürk'ün vefatı dolayısıyla yayınladığ bir makalede; "Onun vefatıyla harp sonrası devlet reislerinin ilki kaybolmuş bulunuyor. Tarih, Yeni Türkiye'nin yaratıcısina diğer liderlerden en fazla takdir edecektir. Cü̈nkü onun karşılaştlğı vaziyet en ümitsiz vaziyetti. Kırılmaz bir enerji ile başladı ̆̆ ve neticelendirdiği eser, müşüllerle en fazla dolu olanı idi. Mesele yalnı bir milleti siyaseten yükseltmek ve ona milletler manzumesinde yeniden itibarl bir mevki kazandırmaktan ibaret değildi. $O$ milleti, asırlık uykusundan uyandırarak ruhunda değişiklik yapmak icap ediyordu. Ĕ̆er Mustafa Kemal yalnız Avrupa'ya karşı mücadele etmek mevkiinde kalmış olsaydı bile bu is başlı bașına fevkalade sayılabilirdi. Hâlbuki Atatürk tasarladığı hedefe varmak için içtimai bir çerçeveyi kırmak, bir teokrasiyi imha etmek, adetleri alt üst etmek, ortaçağdan beri yer etmiş ananeleri ve batıl akideleri kökünden sökmek mecburiyetinde kalmıştı. 10 sene içerisinde Türkiye'yi beş, altı asır ileri götürdü. Buna rağmen tek başına denebilecek kadar yalnız çalışıyordu. Başkaları gibi büyük bir milli hareket onu sürüklemiş değildi. Hatta çoğu zaman onun aleyhinde çalışılıyordu. $O$, azmi sayesinde bütün zorlukları yendi... Hayret uyandıracak sebepler bakımından çok bereketli olan yaşadığımız devrin bu hususiyetine răgmen, en harikulade adamlardan biri olan Atatürk'ün hatırasını onun şahsiyetine karşı borçlu olduğumuz takdir ve hürmetle selamlayalım" ${ }^{\prime \prime}$ derken gerçek anlamda Atatürk'ü tanımlayabilmiş ve bu özel yorumu Cumhuriyet gazetesi de aynen vermiştir.

Illustration mecmuasının Cenevre muhabiri Noelle Roger, Atatürk hakkında yayınladığı makalesinde; harp sahasında zafer kazandıktan sonra, ilim ve iktisat sahasında mücadeleye atılan Atatürk'ün bu vadide ilk zaferi, Ankara'y1 kurmaktaki mucizesi olduğunu söyledikten sonra harf inkılâbından bahsederek bu büyük eserin nasıl mantıklı bir plan ve muntazam bir mesai sayesinde vücuda geldiğini izah ederek dil inkılâbı sırasında Atatürk ile ilk defa görüştüğünde O'na ait intibalarını şöyle anlatmaktadır: "O'nun gözleriyle bir kez karşılașınca bir daha unutmak imkânı yoktu. Bu gözler, o kadar derin ve o kadar irade doluydu ki, bakışlarına mukavemet etmek bir delilik olurdu. O'nun insana bir defa bakması kâfiydi. Çünkü istediğini elde edeceğine kanaat getirmiştir. Türklerin babası kendisinden hiçbir şey esirgemeyen milletine bir baksa yeter... 'Yorgunluk denilen şey, mevcut değildir' diyen Atatürk, vekillerine iki saat uykuya ihtiyacım var iki saat sonra gelin derdi. Gün doğmadan önce kesinlikle uykuya yatmaz az uyur, kalktığında yüzmeden sonra tekrar

${ }^{49}$ Mehlika Aktok Kaşgarlı, "Kurtulus Savașında Türk-Fransız İlișkileri ve Mustafa Kemal Atatürk'ü En İyi Anlayan ve Tanıyan Fransız Devlet Adamı Adouard Herriot”, 4. Uluslararast Atatürk Kongresi, I, Ankara 2000, s. 192; Baycu, a.g.m., s. 396.

${ }^{\text {so }}$ Paris'te haftalık olarak çıkmıştır.

51 "Atatürk ve Avrupa", Cumhuriyet, 20 Kasım 1938, s. 8. 
çalışmaya başlardı. Ruhunu teşkil ettiği büyük memleketin çeşitli işleriyle ve Avrupa siyasetinin karışık safhalarıyla uğraşır, aynı zamanda sevdiği mevzular üzerinde tetkikatta bulunurdu... Orta boylu olduğu halde çok yüksek görünen Atatürk, süratli yürüyüsü, cevval insanlara has keskin jestleriyle etkileyici bir liderdi. Özellikle Türklerin menșei meselesi üzerinde duruyordu... Yenilmez bir iradeye sahipti. Iyi kalpli, insan bir adam Türk milleti onun şahsinda kendisini görüyordu" ${ }^{32}$.

Atatürk'ün sağlık problemleri nedeniyle kendisini muayene eden Fransız doktor, Şarl Fisenje'nin, Journal des Praticien mecmuasında onunla ilgili yayınladığı bir makaleye dair Cumhuriyet gazetesinin verdiği habere göre, O'na ve büyük eserine hayran olduğunu ve birkaç gün içinde Türkiye'nin bütün tarihini gördügünü söyleyerek; "1919'da Türkiye bitmişti. Büyük harp onu bitirmişti. Ordunun silahı kalmamıştl. Ittilaf Devletleri, memleketin büyük bir kısmını işgal etmişlerdi. Artık Türkiye yoktu. Mustafa Kemal milli ruhu yeniden kurmak zaruretinde kalmış, yeni baştan bir ordu yaratmış Türkiye'yi kurtarmıştır. Türklerin İstiklal Harbi dedikleri bu harekettir. Bir yandan imar ederken bir yandan da yurtseverlik bakımından zaafi, Türkiye'nin batmasına sebep olan eski içtimai bünyeyi yıkmak lazımdi" "53 yorumunu yapmıştır.

Pier Dominik'in ${ }^{54}$ Atatürk için yazdığı makaleye dair Ulus gazetesi verdiği haberinde büyük liderin hayatını ve liderlik özelliklerini gerçek yönleriyle değerlendiren şu satırlara yer vermiştir; "Kemal Atatürk olmasaydl yeni bir Türkiye görecek miydik? Belki de haylr. Mutlak bir bozgun arasında, en faciall şartlar için de o, bunca zamandan beri köhnemiş ve çürümüs eski Türkiye devletinden ilk hamleleri dünyayı hayrete düşüren ve yirmi seneye yakın bir zamandan beri mağlubiyet tanımamış olan yeni canlı ve kudretli bir devlet çıkarmıştır. Sürülmüş ve kanun dışı edilmiş olan Kemal Atatürk, Anadolu'ya hareket ettiği zaman resmi idare ve İtilaf Devletleri onun düşmanıydı. İdeali uğrunda hayatını fedaya amade fakat aynı zamanda bu ideale Türk ve yabancı başkalarının hayatlarını da fedaya amade idi. Vatanperverleri etrafina topladl, yeni bir hükümetin esaslarını kurdu. Silahı eline aldı, üç sene süren çetin bir harpten sonra Yunanlllart mağlup etti" dedikten sonra bu arenada Fransızların ve İngilizlerin rolüne de değinen Dominik, büyük liderin üstün vasıfları karşısında mağlup olduklarını söyleyerek şöyle devam etmiștir;"Bir an sahilde tsrar etmek isteyen fakat nihayet geriye çekilen Ingilizlere rağmen İstanbul'u aldı. Bundan sonra Fransizlara döndü ve o kadar maharetle hareket etti ki, biz Çukurova'yı tahliye ettik ve Suriye ile birlikte müdafaası imkânsız bir hatta kadar geri çekildik. Onun siyasi ve içtimai reformatör rolü üzerinde ısrar etmiyorum. Türkiye'den geri kalan 750 bin km. arazi üzerinde 15-16 milyon

52 "Türklerin Babası Türkiye'nin Kalbinde Ebediyen Yaşayacaktır", Cumhuriyet, 29 Kasım 1938, s. 3 .

53 "Bugünkü Türk Bir Avrupalıdır, Faaliyeti, Tavrı Bunu Anlatıyor", Cumhuriyet, 29 Kasım 1938, s. 3.

${ }^{54}$ Fransiz Gazeteci. 
insanı avucuna aldı ve aynı azim ve bazen şiddetle onu modernleştirme işine girişti. Bu, insan gücünden üstün bir işti. Çünkü burada karşısında ordular değil, bir dini zümre, ananeler ve bir cihetten vicdanlar vardl. Bununla beraber bütün engeller aşıldı. Bugün Türkler dört, beş yüz sene önce Avrupa'y titreten canlı millet haline gelmiştir. Şunu da bilirim ki, eserine bütün gayretiyle girişen Kemal Atatürk, yaşadı̆̆ı müddetçe yolundan şaşmadı ve 1919'dan beri çelik elini asla açmadı. Kemal Atatürk, büyük bir siyasi ve büyük bir reformatör olmadan önce büyük bir kahramandl. Haritaların tekrar eline ald ve harbi kazand ve ancak sonra kendisini tedavi ettirdi" ${ }^{55}$.

Paris'te aylık bir mecmua olarak çıkan Florian Delhorbe is e Cumhuriyetin 15. yıl dönümü münasebetiyle yayınladığı bir makalede Atatürk için; "Türkiye beynelmilel işlerde giderek genişleyen büyük bir yer işgal etmektedir. Bu sefer Balkan Antantı'nın başında olarak tarihte ikinci defa Tuna kıyalarına geldi. Aynı zamanda muslihane diğer bir akım onu Asya Paktı vasıtasıyla Himalaya'nın eşiğine kadar götürdü. Ankara, Almanya ve Ingiltere arasında sikı bir nüfuz mücadelesinin cereyan ettiğ i diplomasi merkezi haline geldi. Fransa oraya yeni bir sefir gönderdi. Devlet adamları ve iş adamları Türkiye hakkındaki mütalaalarında tamamen yanılmışlardır. Profesyonel ekonomi mütehassislarl hata işlemek hususunda hiçbir zaman firsat kaçırmazlar... Times gazetesi 9 Ağustos 1938 tarihli sayısında, büyük harbi takip eden ihtilallerden hiç birisinin Türk ihtilali kadar beklenmedik bir mahiyet taşımadı̆̆ını yazıyor. Çünkü Türkler, asırlarca müddet Avrupa'da kaldıkları halde Avrupalılaşmadıkları için bunun sonsuza kadar böyle devam edeceğini düşünüyorlardı. Bu hatayı umumiyetle Türk zihniyeti hususundaki cehaletle izah edebiliriz. Bir milletle, onu idare eden güzide sinıf arasinda mevcut münasebetler bahsindeki mutlak bilgisizlikte ayrıca bunu izah eden bir sebeptir... Sevr Antlaşmasını genç Türkiye'nin muzaffer ordularl derhal yırttı" "56 cümlelerini kullanırken bundan sonra da devam eden ölüm kalım mücadelesine de değinmiş 9 Eylül'de bitirilen savaşın sonunda ki zafer sevincinin arkasından başlatılan yeni mücadele anlatılmıştır.

Gerçekleştirilen bütün bu mücadelenin Türklerin kahramanlığı sayesinde başarıldığı da vurgulanmıştır. Makalenin devamında yapılan yorumda masa başında kaybeden bir milletin yeniden diriliş öyküsü şöyle anlatılmıştır; "Türkler Büyük kumandanlar yetiştirmişlerdir. Fakat harp bittikten ve ganimetler paylaşıldıktan sonra askerler köylerine dönerlerdi. Harpte muzaffer olan millet sulhta kabiliyetsiz idare adamlar yani rejim menfaatperestleri tarafından ihanet görürdü. Generaller yenmesini biliyorlar, fakat zaferden istifade etmesini bilmiyorlardl. Burada Mudanya Mütarekesi bir dönüm noktası olmuştur... Türkiye parçalanıyordu. Bu büyük tehlike karşısında, memleket büyük generaller ve bir lider bulmak

55 “Kuvvetli ve Dirilmiş Canlı Bir Türkiye'dir", Ulus, 18 Kasım 1938, s. 5.

56 "Bir Fransız Mecmuasına Göre Yeni Türkiye", Cumhuriyet, 19 Kasım 1938, s. 3. 
mazhariyetine erdi. Hitler'den ve Mussolini'den önce bir Mustafa Kemal ortaya çıktı. Atatürk, ana ve babasından büyük seciyeleri yaratan iki büyük kuvvete tevarüs etmişti... Harp bittikten sonra eski mesele yeniden ortaya atılmıştı. Osmanlı Devleti yeniden modern bir devlet olabilir miydi? Yoksa yabancı bir devletin vesayeti altında bir ortaçă̆ teokrasisi olarak kalmaya mı mahkûmdu? Galip devletlerin cevabı gecikmedi. Küflenmiş imparatorluğun bakiyelerini paylaşmaktan başka yapacak şey yoktu. Fakat galipler, imparatorluk öldükten sonra Türkiye'nin yaşadığını, topră̆ından ordularla kahraman asker fişkırtmaya muktedir olan memleketin henüz son sözünü söylemediğini ve bu memleketin bir şefe yani azme ve idareye sahip olduğunu anlamamışlardı. Bir tek adam iki işi birden ele almış yürütüyordu. Devlet adamı ve halk çocuğu Atatürk, kendisini maruz hisseden her millet gibi Türk milleti de başının çaresine bakmak için şefinin sevk ve idaresi altında, Anadolu'nun yalçın tepelerine çekilmişti... Türkiye'nin doğuşunu temin edecek olan yeni ruh, Anadolu'nun ortasında kendisini göstermişti... Atatürk birçok meziyetlere sahip bir milletin ${ }^{57}$ desteğine güveniyordu" . Makale, Atatürk'ün savaştan sonra gerçekleştirdiği icraatlarına yer verdikten sonra șu cümle ile bitmiştir; "Türkiye bir tek insanın memleketinin yükselmesi hususunda nelere kadir olabileceğini gösteren en kuvvetli bir misaldir" 58

Fransız basını, bir yandan bu şekilde uzun makalelerle Atatürk'ü yâd ederken diğer yandan da 12 Kasım'da Ankara'da bir koloni oluşturup, Ulus meydanındaki Atatürk anıtına giderek, Türk ve Fransız bayraklarının renklerini havi büyük bir çelenk koymuşlar ve cenaze törenine İçişleri Bakanı ve Eski Ankara Büyükelçisi Albert Sarraut'un ${ }^{59}$ başkanlığı altında oluşturulan özel bir heyetle katılmışlardır. ${ }^{60}$ Heyete, yüksek harp meclisi

${ }^{57}$ Elisee Reclus, Türk milletini söyle tarif etmektedir: "iktidarın mürtekipliğe sevk edemediği, istibdadın ifsad edemediği Türk, hiç şüphesiz meziyetlerinin heyet-i umumiyesiyle en fazla beğenilen insanlardan biridir. Türk asla aldatmaz, namuskâr, doğru, hakikatperestir. Kendinden olanlarla tesanüdü çok fazladır, varını memnuniyetle paylaşır ve kendisi bir şey istemez. Ne denirse densin bahşiş suistimali Avrupa'da şarktakinden daha fazladır. En mağrur ve en kuskkulularda dâhil olmak üzere bir tek seyyah var midır ki, Türk köylüsünün samimi ve hasbi konukseverliği karsısında derin surette mütehassis olmus olmasın". Böyle insani vasiflara sahip bir millette gelişme ve ilerleme imkânlarl da o nispette büyüktür". Bkz. "Bir Fransız Mecmuasına Göre Yeni Türkiye", Cumhuriyet, 19 Kasım 1938, s. 3.

58 "Bir Fransız Mecmuasına Göre Yeni Türkiye", Cumhuriyet, 19 Kasım 1938, s. 3; K.S. Chantitch, 1929 'daki bir yazısında şöyle demektedir: "Bu ülkede, önemli değissiklikler gerçekleșmis ise bu Mustafa Kemal Pașa sayesinde olmuștur. Bu günün Türkiye'sinde bütün reformların hazırlayıcısı ve yürütücüsü odur. Yeni cumhuriyetin reform devri, Mustafa Kemal'in zihniyetinden o derece etkilenmiştir ki, ekonomik, sosyal, siyasi ve fikri bir meselenin incelenmesi, büyük reformcunun sahsiyeti üzerinde durulmadan yapılamaz. Bu sebepledir ki, Mustafa Kemal Paşa, ülkenin ruhu haline gelmiştir. Yeni Cumhuriyet, Mustafa Kemal' in fikirlerinin simgesinden ibarettir". Bkz. Baycu, a.g.m., s. 394.

59 Albert Sarraut, Türkiye'ye tören için geldiğinde yaptığ açıklamada sunları söylemiştir, "Türkiye'de sefir bulunduğum müddet içinde itimat ve dostluk hisleriyle beni taltif eden Atatürk'e o zamandan beri derin hayranlı̆̆ım vardır. Emin olunuz ki, bütün Fransa onun kıymetini takdir ediyordu. O, cok büyük bir inkılâpçıdı. Büyük inkılâbınız onun en büyük eseridir. "Çankaya'daki Güneş", Akşam, 20 Kasım 1938, s. 3.

$\left.{ }^{6}\right)$ Olusturulan koloni, konsolos Ganet'in ve Ankara'nın eski Fransız sakinlerinden Casalonca'nın idaresinde kurulmuş, ayrıca Fransız Büyükelçilik erkânı da bu merasime 
azasından General Georges ${ }^{61}$ ve Yüksek Bahriye Meclisi azasından Amiral Laborde'den başka 180 kişilik bir askeri birliğin de katılmasına karar verilmiștir. Ayrıca Fransa'nın Suriye Komiseri Kont de Martel ve doğudaki Fransız kuvvetleri kumandanı General Caillavit, cenaze merasiminde temsil edilecekti. Albay Kole'de heyete dâhil olup ayrıca Emile Bertin ismindeki Fransız kruvazörü de merasime katılmak üzere İstanbul'a gelecekti ${ }^{62}$.

\section{C-Almanya'daki Akisler}

Almanya, her zaman Atatürk'ün eserine ve verdiği mücadeleye büyük bir hayranlık duymuştur. Hatta O'nun hayatının Almanya'da olduğu kadar hiçbir yerde gerçek anlamda anlaşılıp takdir edilemeyeceğini dahi ileri sürmüştür. Çünkü Almanya da, Türkiye'nin geçtiği yoldan geçmiş, I. Dünya Savaşı sonucunda İtilaf Devletleri tarafından Türkiye'ye empoze edilen barış şartları Almanya için de geçerli kılınmıştı. Arada bir kader birliği vardı. Bunun için Alman basını, sürekli olarak Atatürk'ün başarılarına yer vermiş hatta çoğu zaman da örnek dahi almıştır.

Aynı durum ölümünden sonra da devam etmiş ve Alman gazeteleri Atatürk'ün ölüm haberini büyük başlıklar altında, uzun tercüme-i haller ve fotoğraflarla neşretmişler, O'nun için baş makaleler ve makaleler yayınlamışlardır. Almanya'da çıkan haberleri günlük olarak takip eden Türk basını ise gazetelerinde bu haberleri bazen aynen, bazen de özet şekilde vererek büyük liderin dünyadaki akislerini ülke kamuoyuna yansıtmaya çalışmışlardır. Ulus, Akşam ve Tan gazetelerinin $15 \mathrm{Kasım}$ tarihli nüshalarında, büyük liderin ölümünün Almanya'daki yankılarına yer verilmiştir. Yapılan bir yorumda şöyle yazılıdır; "O Memleketini müzakerelerle ve Cenevre metotlarıyla kurtaramayacağına kani olarak mücadele yolunu ihtiyat etti. Yalnız çelik bir irade ve kuvvet muvaffak olabilirdi. Memleket içindeki eseri daha az hayranlığa layık değildir. Almanya Atatürk'ün eserine ve mücadelesine hayrandır. Onda, hürriyeti seven bütün milletler için bir sembol olarak kalacak kudretli bir şahsiyet görmektedir. Atatürk şahsiyetinin kuvvetiyle milletleri dâhilen ve haricen değiştiren harp sonrası şefleri arasında daima hususi bir yer işgal edecektir. O, yeni Türkiye'nin yaratıcısı ve kurucusu olmuş, Yakın Doğu'nun şimdiki çehresini tespit etmiştir" ${ }^{03}$.

Tan gazetesinin verdiği habere göre, Berlin'deki Berliner Tageblat gazetesi ise; "Atatürk ne kadar ă̆ır olursa olsun hiçbir yenilginin sağlam bir milletin varlı̆̆ını zaferle devam ettirmek için lazım olan kuvvetleri harekete getirmesine engel olamayacağını bundan 20 yıl kadar evvel

katılmıștır. Kalabalık bir halk kitlesi de merasimde hazır bulunmuştur. Bkz. "Ankara'daki Fransız Kolonisi", Akşam, 13 Kasım 1938, s. 2; "Büyük Yasımıza İştirak Edenler”, Ulus, 15 Kasım 1938, s. 5.

${ }_{61}$ Daha sonra General Georges'in yerine Şark kuvvetleri komutanı General Huntzinger'in katılmasına karar verilmiştir. Akşam, 18 Kasım 1938, s. 7.

${ }_{62}$ "Fransız Heyeti", Ulus, 17 Kasım 1938, s. 3.

63 "Büyük Yasımıza İștirak Edenler”, Ulus, 15 Kasım 1938, s. 5; “Almanya Atatürk'ün Eserine ve Mücadelesine Hayran”, Akşam, 15 Kasım 1938, s. 2; "Ulu Şefimize Dünya'nın Hayranlığı”, Tan, 16 Kasım 1938, s. 7. 
dünyaya ispat etmiştir. Bu büyük adamın vakitsiz ölümü biz Almanları derin ve candan bir matemle sard" diyerek, O'nun tarihi eserinin kıymetinin daha sonra çok daha fazla anlaşılabileceğini de belirtmiştir ${ }^{64}$.

Börsen Zeitung gazetesi de, Atatürk'ten "En Büyük Türk” olarak bahsetmekle beraber, haleflerinin onun mirasını korumaları gerektiğini de vurgulamıştır. Deutsche Allgemeine Zeitung gazetesi ise, böyle büyük bir adamın bir daha dünyaya geleceğini zannetmediklerini ve onun gerçek büyüklüğünün zamanla ortaya çıkacağını yazmıştır ${ }^{65}$.

Akşam gazetesinde yer alan habere göre Berlin'de Völkischer Beobachter gazetesi, "Dünya'nın Hayran Kaldığ Bir Kalkınma" başlığı altında Atatürk hakkında yaptığı yorumunda; "Gazi 1918'de ölen milletler grubu arasinda azimli bir hareketle milletini tahammül edilmez bir diktadan kurtaran ve bütün dünyanın hayran kaldığ bir kalkınmayl yapan ilk devlet reisi olmuştur. Atatürk tarihin büyükleri arasında ebedi bir surette gözükecektir" ${ }^{66}$ dedikten sonra O'nun Türk milletine yeni bir medeniyet kuvvetli ve feyizli yeni bir devlet miras bıraktığını, Türkiye'nin de bu mirası korumasını temenni etmiştir. ${ }^{67}$

Yine aynı gazetenin bir başka makalesinde de Atatürk'e geniş yer ayrılmış ve Türk milletinin en büyük oğlunu kaybettiğinden bahisle, O'nun başarılarından söz edilerek; "İcraat adamı olan Atatürk, memleketin ihya ve imarını dâhili islahat ve komşularla takip edilen bir dostluk politikasılyla temin etmiştir. Dış politikadaki büyük muvaffakiyetleriyle bu büyük asker ve bu dahi devlet adamı 1918'den 1922'ye kadar mücadelelerde olduğu gibi Pasifik işlerinde de büyük başarılara imza atmıştır" ${ }^{18}$ denilmiştir.

Correspondance Politika Diplomatic gazetesi, Atatürk'ün başarısının istiklal hissini taşıyan bütün milletler için ölmez bir sembol olduğundan

64 "Ulu Önderimizin Vefatı Bütün Cihana Derin Bir Heyecan ve Teessür Verdi”, Tan, 12 Kasım 1938, s. 9; Ayın Tarihi, Kasım 1938, s. 175.

65 "Her taraftan Büyük Matemimize İştirak Ediliyor", Akşam, 12 Kasım 1938, s. 2; Ayın Tarihi, Kasım 1938, s. 175. 2 .

66 “Atatürk'ün Ölümü Almanya'da Derin Elem Uyandırdı”, Akşam, 13 Kasım 1938, s.

${ }^{67}$ Başkan Hitler, Atatürk hakkında düşünülen bu fikirleri 1933'de Büyük Millet Meclisi Hariciye Encümeni Reisi ile olan görüşmesi esnasında da bizzat ifade etmiştir. Hitler, Atatürk'ün başarılarının kendisinin Nasyonal Sosyalizm muvaffakiyetine olan inancını vurgulamakta olduğunu bilhassa belirterek, Türkiye'nin kurtuluş mücadelesi parlak bir numunedir dedikten sonra şöyle devam etmiştir: "Türkiye'de ve Almanya'da kuvvetli bir köycülük, milli kuvvetin tükenmez bir kudreti vardır. Iki milletin aynl politik gayeleri mevcuttur" diyerek, Türkiye ve Almanya arasındaki siyasi gelecek bakımından bir bağlantı kurmaya çalışmış ve Almanya ile birlikte Türkiye'de yaşanan ilerleme hızının Almanya tarafından örnek alındığını da özellikle ifade etmiștir. Bkz. "Atatürk Karşısında Dünya'nın Dili”, Kurun, 13 Kasım 1938, s. 3; “Dünya'nın Büyük Kaybı”, Cumhuriyet, 12 Kasım 1938, s. 5; Ayın Tarihi, Kasım 1938, s. 175-176.

“' "Atatürk Karşısında Dünya'nın Dili”, Kurun, 13 Kasım 1938, s. 3; “Atatürk'ün Ölümü Almanya'da Derin Elem Uyandırdı", Akşam, 13 Kasım 1938, s. 2; "Hariçte Duyulan Derin Teessürler", Tan, 13 Kasım 1938, s. 9; "Dünya'nın Büyük Kaybı", Cumhuriyet, 12 Kasım 1938, s. 5; "Atatürk'ün Ölümü Karşısında Dünya Matbuatı", Kurun, 15 Kasım 1938, s. 2. 
bahisle şunları yazmıştır; “Büyük Türk kurtarıcısı Gazi Kemal Atatürk'ün eseri, kendisine sonsuz bir minnet borçlu olan vatanının dışında kendi memleketinin geçmiş olduğu aynı yerlerden geçmiş olan memleket derecesinde bir anlayışa hiçbir yerde rastlayamaz. Türkiye, Almanya ile aynı akıbete uğramıştır. Türkiye, düşmanın tahakkümünden kuşatılmış Almanya'dan daha uzak bulunduğu ve daha ilk anlarda Mustafa Kemal Paşa'nın şahsında, tehlike anında şefini bulmak talihine mazhar olduğu için, bu milli kahramanin sarsılmaz istiklal zihniyeti, hasta adam denilen ve tabii bir ölüme namzet sayllan Türk milletini, peşinde dirilişe doğru yürütmeye ve ecdadının eski şerefini yeniden yaşamaya ve böylece adalet esasina müstenit yeni bir milli istikbalin temelini yaratmaya muvaffak oldu" ${ }^{19}$ dedikten sonra Atatürk'ün dış politikasına da değinerek, bu politikanın siyasi doğru görüşün bir karakteristiği olduğunu söylemiş ve eski düşmanlarıyla barış yaparak onlarla dost olacak kadar büyük bir insan olduğunu da vurgulamıştır.

Atatürk'ün, ülkesinde ve dünyada adil ve takdir edilen bir mevki kazanmasını da takip ettiği bu politikaya dayandıran gazete sonuç olarak bütün bu özelliklerinden dolayı Alman milletinde samimi bir hayranlık bıraktığını belirttikten sonra; “Alman milleti yeni Türkiye'nin kaybettiğ $i$ kurucusunun şahsında tarihi eseri, ebediyen bir örnek kalacak ve aynı zamanda istiklal hissini taşıyan milletler için ölmez bir sembol olacak büyük simalardan birini görmektedir" ${ }^{\text {"70 }}$ diyerek, Almanya'daki Atatürk'ün imajını vurgulamıştır.

Yine Germania gazetesinin, Atatürk'ü yeni Türkiye'nin yaratıcısı ve kurucusu olarak Yakın Doğu'nun kaderini değiştiren lider olarak vasıflandırdığını ${ }^{71} A k s ̧ a m$ gazetesinin haberlerinden öğrenmekteyiz.

Illustrirte Zeitung mecmuası, Atatürk'ün vefatı münasebetiyle yeni Türkiye hakkında yayınladığı makalesinde iki sayfasını resimlerle Türkiye'ye ayırmıştır. "Türklerin Babası" adını taşıyan yazıda Dr. Walther Pahl, büyük liderin tarihi rolünü ve yarattığı eserini dile getirmiş ve şunları yazmıştır; "Çelik gibi azim ve gayreti uză̆ı gören akıl ve hikmetle birleş̧irilmiş olan bu hakiki halk lideri ve devlet adami, Anadolu dağlarının en ücra köşesindeki köylere bile başka bir ruh aşılamıştır... Yorgun ve manevi kuvveti kırılmıș Anadolu köylüleri, uzun seneler devam eden askerlik hizmetinden köylerine dönmüşlerdi. Kapitülasyonlar bütün ă̆ırlı̆̆ıyla memleketin üzerine yüklenmişti. Bu gün ise bir zamanlar Boğaziçi'nin hasta adamı sayılan Türkiye kuvvetli bir memleket olmuş ve kendi mukadderatını kendisi tayin etmiştir. Tekrar cihan politikasının orta noktasında yer almıştır ve bu Atatürk'ün eseridir..." dedikten sonra, Türkiye'de gerçekleştirilen iktisadi ve zirai alanda yapılan çalışmalar ve ulaşım çalışmaları, sosyal hayatta yapılan yenilikler, laikleşme hususundaki faaliyetler, Boğazlar

\footnotetext{
(*k، Almanya'nın Atatürk'e Hayranlığı”, Ulus, 19 Kasım 1938, s. 5.

70 “Almanya'nın Atatürk'e Hayranlığı", Ulus, 19 Kasım 1938, s. 5

71 “Almanya Atatürk'ün Eserine ve Mücadelesine Hayran”, A kş̧am, 15 Kasım 1938, s. 2.
} 
Sözleşmesi ve Lozan Antlaşması'yla elde edilen başarıları uzun uzun anlatmış ve sonuç olarak; "Büyük Almanya, yeni Türk devletinin siyasi metanetine ve iktisadi istihsal kudretine itimadını, Ingiliz kredisi akabinde geniş ölçüde Alman eşya kredisi açmak suretiyle temin etmiş̧ir. Almanya ile Türkiye arasındaki dostane münasebet sağlam temellere dayanmaktadır ${ }^{72,}$ diyerek, genel anlamda Türk-Alman ekonomik ilişkilerini ön plana çıkarmışıır ${ }^{73}$.

\section{D-Amerika'daki Akisler}

Atatürk'ün ölümü Amerika'yı da yakından etkilemiş ve hakkında pek çok yazı yazılmış, kitaplar neşredilmiştir. Gazetelerde Atatürk'ün bütün yönleri uzun uzun tasvir edilmiş en ince ayrıntısına kadar ele alınmış ve onun bu çok yönlü kişiliği ve liderliği, hoş görüsü büyük bir hayranlıkla anlatılmıştır ${ }^{74}$. O'nun hakkında yazılan ve çizilenleri yine Türk basınının verdiği haberlerden öğrenmekteyiz. ${ }^{75}$

New-York Times'da Atatürk ile ilgili çıkan bir yazıy ${ }^{76}$ Kurun gazetesi şu satırlarla aynen vermiştir; "Türkiye'de Türk Cumhurbaşkanı Mustafa Kemal Atatürk'ün barış vaziyeti kadar üzerimde tesir uyandıran bir şey olmamıştır. Hele Osmanlı Devleti'nin daima harpçi bir devlet ve Atatürk'ün bizzat kendisinin de senelerce generallik etmiş, nihayet bir gazi yahut da bir fatih olduğu hatırlanırsa bu vaziyetin dikkate de ğerliği büsbütün meydana çıkar. Atatürk, şimdi hem memleketinin kalkınma ve yeniden imarını amir bir siyasa, hem de gerek komşularl ve gerekse bütün dünya da dostça münasebetler tutma yolunu kollamaktadır. İçerde barış ve dişarıda barışı esas prensip olarak kabul etmiştir. Atatürk, barlşl samimi olarak istiyor. Mazideki savaşların memleketin başına hesapsiz ziyanlar getirmiş olduğunu bildiği gibi bu savaş bahsi hususunda da bu derece hassas ve müdrik olan yegâne kudretli önder görülmektedir".

"Atatürk savaş ve ordu ile siyaseti bir birinden aytrt etmiştir. $O$, general üniformasını hemen hiç giymez. Hatta askeri geçit resimlerinde bile sivil elbise ile hazır bulunur, vaktiyle düşmanı olanların zararına kazanılmış olan zaferleri teyit etmezdi. Özellikle Amerikall bir sefir, Fransa da adet olduğu veçhiyle Türkiye'de de harp meydanlarını gezmek için müsaade istediği zaman Atatürk, bu meydanlarda kazanilan zaferlerini yâd etmektense, vaktiyle düşman olan Yunanistan ile Türkiye arasında şimdi

72 “'Almanlar Kemalizm'i Nasıl Görüyorlar”, Cumhuriyet, 20 Kasım 1938, s. 9.

${ }^{73}$ Almanya'dan cenaze merasimi için Türkiye'ye gelecek heyette, Müșavirler Meclisi başkanı Baron Von Neurath, Ordu Kumandanı General List, Amiral Ceris, General Felmi, Ortaelçi Von Kutze, Sefaret Müsteşarı Braun Von Stumm, sefaret kâtiplerinden Von Kessel, Albay Kettenbeil, Yarbay Von Rost, Mülazim Belge bulunmaktaydı. Bkz. "Alman Heyeti", Ulus, 17 Kasım 1938, s. 3.

${ }^{74}$ Kurun, 13 Kasim 1938, s. 2.

${ }^{75}$ Cenaze merasiminde Amerika Birleșik Devletleri Cumhurbaşkanı Ruzvelt'i, Ankara Büyükelç̧isi Mac Murrey’in temsil etmesi kararlaştırılmıştır. Bkz. Akşam, 18 Kasım 1938, s. 7.

\footnotetext{
${ }^{76}$ Bu yazı bir Amerikalı gazeteciyle yapılan mülakattan alınmıştır.
} 
mevcut olan samimi ve dostça münasebetlere şahit olmayl tercih ettiğini söylemişti".

“Yine Atatürk'e Türkiye'nin Yunanlıların Anadolu'da yaptıklarl tahribata mukabil, niçin Yunanistan'dan tazminat istemediği sorulduğu zaman, Atatürk'ün bana verdiği cevap, Türkiye ile Yunanistan arasında gittikçe gelişen ticari münasebetlerin Türkiye için, her halde bu şekilde sıkıcı tazminattan çok daha faydall olduğunu söylemesi olmuştu. İste bu telakki ve bu cevaptan daha makul bir şey olabilir mi? Atatürk'ün yaptığ anlaşmaların en önemlisi 1934 Türkiye, Yunanistan, Romanya ve Yugoslavya tarafindan imzalanip da maalesef Bulgaristan ile Arnavutluk'un iştirak etmedikleri Balkan Antlaşma Paktı olmak şartlyla, hepsi saldırmamazlık, ademi tecavüz paktlarıdır. Bu da işte şimdiki sınırların muhafazasıyla saldırmazlık için akdedilmiş bir anlaşmadır. Atatürk'ün gerek Türkiye'de, gerek Türkiye'nin bütün dünya ile olan münasebetlerinin tanzimi için de barışı esas tutması, hem harbin külliyen arzu edilmeyecek bir şey olduğunu takdir edişi, hem de savaşa meydan verecek bütün geçimsizlik amillerinden iyice kaçınmasını bilişinden doğmaktadır"77.

New -York Herald Tribün gazetesinde George Benneb'in Atatürk ile ilgili çıkan bir yazısına dair Kurun gazetesinin verdiği haberde büyük lider için; "Tarihte büyük diplomatın veya meşhur bir kumandanın hayatını okuduğumuz zaman, onun yüzünü, sözünü, bakışlarını tahayyül etmekten zevk duyar ve kendi kendimize onu görsek ve tanısak ne iyi olurdu deriz. Bu gün Türkiye'nin mukadderatını idare eden büyük diplomat, büyük asker ve büyük inkılâpçı Kemal Atatürk'ün heyecanlı yıllar geçtikten sonra hayranlıkla öğrendikleri zaman, hiç şüphesiz çocuklarımız da böyle düşüneceklerdir. Ateşli bir inkılâpçı olduğu için, dönemin iktidarlyla ters düşmesine rağmen, kumandanlık yaptığı zaman galip gelerek ülkesine istiklalini kazandıran devlet reisi sifatıyla cumhuriyeti ilan edip kurumlandıran Atatürk'ün hayatl elbetteki heyecanlıdır ${ }^{78 "}$ "cümleleri kullanılmıştır.

Makalenin devamında ise Atatürk'ün bütün hayatına hâkim olan temel prensipten bahsedilmiş ve O'nun ülkesine olan sevgisi dolayısıyla milletine ne kadar büyük hizmetlerde bulunduğu vurgulanmıştır. Atatürk'ün bağrından çıtı̆̆ı Türk milletine büyük bir sevgiyle bağlı olduğunu ve milletinin unutulan tarihinin yeniden araştırılması için bir heyet oluşturduğunu ve bu heyetin Türklerin orijini ve eski medeniyetler üzerinde ne gibi tesirleri olduğunu araştırıp yazmaları için emir verdiğini de belirtmiştir. Bu çalışmaların sonunda dört cilt tarih kitabı meydana getirildiği gibi yabancı okullar da dâhil olmak üzere bütün okullarda okutulmuştur. Yazara göre oluşturulan bu eser, pedagojinin bir şah eseriydi ve Atatürk'te büyük bir öğretmendi. $\mathrm{O}$, bu çalışmalarla milletini gerçek atalarına bağlamak suretiyle Arap nüfuz ve tesirinden de kurtarmıştı. Bu maksatla $O$, Türk dilini

$\pi$ “'Kemal Atatürk'ün Vaziyeti Hayranlığa Değer”, Kurun, 13 Kasım 1938, s. 2.

78 "Kemal Atatürk ve Onun Eseri”, Kurun, 13 Kasim 1938, s. 2. 
mükemmel ve muntazam bir milli dil haline sokmak için de çalışmışt1 ${ }^{79}$. Bütün bu değerlendirmelerde O'nun üstün yönleri ele alınmış ve ne kadar büyük bir lider olduğu vurgulanmıştır.

New -York Herald Tribune gazetesinde Hester Donaldson Jenkins, “Atatürk büyük Bir Öğretmendir" adlı makalesinde, O'nun eğitim alanında gerçekleştirdiği inkılâp hareketleriyle birlikte diğer alanlarda da yapılan çalışmalara dair şu yorumu yapmıştır; "Bu gün dünyanın hiçbir yerinde Türkiye'nin karşılaştığı pedagojik meselelerden daha büyü̈̆̈̈ olmadı̆̆ gibi, hiçbir yerde de kimse tarafından bu hususta Cumhurbaşkanı Kemal Atatürk'ten daha kati ve cesur teşebbüslere girişilmemiştir. 1923 senesinde, yeni cumhuriyet rejimi kurulduğu zaman Atatürk, gerek toprakların elden çıkması, gerek mübadele ve sair sebepler dolayısıyla memleketten ayrılmıs binlerce Hıristiyan ekalliyetin o zamana kadar gördüğ̈̈ işleri devralacak fakat dünya düsünüs ve ticaret hareketlerinden haberi olmayan, ekserisi ümmi bir halkın başına geçerek onları mutlakıyet idaresinden çıkarıp kendi kendilerini idareye muktedir bir hale getirmek vazifesini üzerine almıştı. Bu halkın Müslüman dini dolayıslyla asırlarca Arap nüfuz ve tesiri altında kalmış olduğunu gören Atatürk, devleti hilafetten ayırmak suretiyle millete tabi ve ırki esaslar üzerinde bir inkişaf imkânı bağıșlamıș oluyordu. $O$, muvaffakiyetli Avrupa metotların tam bir surette tatbik ederek yüksek bir Türk kültürünün inkişafinı arzu ediyordu. Türkiye, garplı olmamıştl, o, yalnız kendi milli karakterinin ve memleketinin gelişmesi için garbı bir vasita olarak kullanmışıtı" ${ }^{\prime \prime 0}$.

Ulus gazetesinde çıkan bir haberde, Amerika Birleşik Devletleri'nin eski Türkiye Büyükelçisi Charles H. Sherrill'in, O'nun için yaptığı açıklamasına yer verilmiştir. Charles $\mathrm{H}$. Sherrill, büyük adamlar yetiştiren bir ırkın, büyük bir ırk olduğundan bahisle o gün için her hangi bir yerde kendisinden daha üstün bir devlet adamı bulunmadığını, cihanşümul bir lider ve devlet adamı olduğunu, kendisiyle uzun saatler süren görüşmelerinde Atatürk'ü daha iyi tanıdığını ve tetkik ettiğini belirtmiştir. Özellikle harikulade ve mükemmel bir kişiliğe sahip olduğunu, akıllara hayret verecek kadar keskin zekâlı ve çalışkan olduğunu, dimă̆ 1 sayesinde Türk milletinin parlak bir geleceğe sahip olduğunu da söylemiştir ${ }^{81}$.

Ayrıca Sherrill, Çankaya'ya yaptığı ilk ziyaretini anlatırken de Atatürk'ü ilk gördüğü an, zihninde oluşan portreyi şöyle ifade etmiştir; "Mustafa Kemal, her şeyden evvel tam manasiyla sihhatli, sağlam ve kuvvetli bir kumandan, metin, geniş simall, derin ve mütekâsif düşünceli, sert ve canlı sözlü bir zattl. Onunla biyografisi için yaptığım yorucu mülakatlar bana, karşımdaki zatın harikulade kuvvette ve mükemmel slhhatte bir adam

79 "Kemal Atatürk ve Onun Eseri”, Kurun, 13 Kasım 1938, s. 2; Yabancı Gözüyle Cumhuriyet Türkiyesi, s. 57.

${ }^{80}$ Yabancı Gözüyle Cumhuriyet Türkiyesi, s. 50-51.

${ }^{81}$ Charles H. Sherrill, "Ecnebi Gözüyle Atatürk", Ulus, 11 Kasım 1938, s. 3; Yabanct Gözüyle Cumhuriyet Türkiyesi, s. 21-23. 
olduğuna şahit olabilecek kararı vermiştir. Cihan Harbi'nden beri gayet yorucu ylllarda milleti için hayretlere şayan neticeler elde etmiş ve hiç şüphesiz daha birçok seneler de devam edecektir... Onunla yaptı̆̆ım mülakatlar, Avrupa'nın diğer mümtaz devlet adamlarlyla olan mülakatlardan bariz bir farkı vardı. Gazi, ansızın masadan büyük bir kâğıt paçası alır, renkli bir kurşun kalemle harp teferruatının resmini çizer yahut anlattı̆̆ mülakatlarda bulunan şahısların yerlerini tespit ederdi... Böylece hikâyeyi yalnız basit ve pürüzsüz bir șekilde anlatmakla kalmıyor, fakat onun krokileri sayesinde sanki sizde bizzat odada imissiniz gibi vakayl hissediyor ve geçen her seye sahit oluyorsunuz... ${ }^{82}$ " dedikten sonra, O'nun inkılâplarından da bahsederek bu inkılâpları yabancı boyunduruğuna karşı kazandığı hürriyet, sevgili anayurduna karşı icra ettiği en büyük hizmetlerden biri olarak saymıştır. Charles $\mathrm{H}$. Sherril, bütün ziyaretlerini bu şekilde uzun uzadıya anlatırken O'na olan hayranlığını hiçbir zaman gizlememiş, kendisinde bıraktığı unutulmaz etkiyi özellikle vurgulamıştır. ${ }^{83}$

Şöyle ki Doğu milletleri, barış içinde yaşamalarıyla birlikte ilerlemelerini de Atatürk'e borçludurlar. Atatürk'ün dünya barışı yolundaki çabaları hiç kuşkusuz yabancı devlet adamlarını ve bilim dünyasını etkileyen en önemli yanı olmuştur. New-York Times'ta yayınlanan bir makalesinde Hester Donaldson Jenkins ${ }^{84}$, O'nun dünya barıșına yaptığı katkıyı anlatırken; "Atatürk şimdi hem memleketinin kalkınma ve yeniden imarın amir bir siyasa hem de gerek komşuları ve gerekse bütün dünya ile dosţ̧a münasebetler kurma yolunu tutmaktadır... Atatürk barışı samimi olarak istiyor. Mazideki savaşlarının memleketinin başına hesapsız ziyanlar getirmiş olduğunu bildiğ $i$ gibi, bu savaş bahsi hususunda da son derece hassas ve müdrik olan yegâne kudretli önder görünmektedir ${ }^{85}$ " cümlelerini kullanmıştır. Bütün bu yorumlardan da anlaşıldığı gibi O'nun yurtta barış dünyada barış ülküsü gerçek anlamda bütün insanlığı etkilemiştir.

82 "Çankaya'ya Yaptığım İlk Ziyaret”, Kurun, 13 Kasım 1938, s. 2.

${ }^{83}$ Cumhuriyetin ilanının yedinci yıldönümü şerefine, 29 Ekim 1930 gecesi tertiplenen baloda Associated Press Muhabiri Miss Ring'in. Türkiye'nin hangi bakımlardan Amerikalılaşmasının düşünüldüğünü sorması üzerine Atatürk, şu cevabı vermiştir; "Türkiye bir maymun değildir ve hiçbir milleti taklit etmeyecektir. Türkiye ne Amerikalllaşacak ne de batılılasacaktır. O sadece özlesecektir" cümlesini kullanmıs olması hiç șüphesiz ki muhabir üzerinde büyük bir etki bırakmıştır Bkz. Avcl, a.g.m., s.407, Şöyle ki, bugün modernleşme yolunda ki yakın doğu ülkeleri ile karşılaştırıldığı zaman Türkiye'nin onlardan tamamen farklı ve batı uygarlığının esaslarına kendi milli benliğinden ve değerlerinden ödün vermeden benimsemiş olduğu görülmektedir.

84 5 Temmuz 1936 tarihli New-York Times gazetesine verdiği demecinde Türkiye'ye yaptığı ziyaretten elde ettiği izlenimlerini șu șekilde aktarmıștır. "Yeniden ziyaret etmekte olduğum yeni Türkiye'de, Türk Cumhurbaşkanı Mustafa Kemal Atatürk'ün bartş vaziyeti kadar üzerimde tesir uyandıran bir sey olmamıstır. Atatürk'ün bizzat kendisinin de senelerce generallik etmis, nihayet de bir gazi yahut da bir fatih olduğu hattrlanırsa, bu vaziyetin dikkate değerliği büsbütün meydana çıkar. Atatürk şimdi hem memleketinin kalkınma ve yeniden imarını amir bir siyasa hem de gerek komşuları ve gerekse bütün dünya ile dostça münasebetler tutma yolunu kollamaktadır... Atatürk barıșt samimi olarak istiyor. Mazideki savaşların, memleketinin başına hesapsız ziyanlar getirmiş olduğunu bildiği gibi bu savaş bahsi hususunda da bu derece hassas ve müdrik olan yegâne kudretli önder görüinmektedir". Bkz. Yabancı Gözüyle Cumhuriyet Türkiyesi, s. 47.

${ }^{85}$ Hester Donaldson Jenkins, "Ecnebi Gözüyle Atatürk", Ulus, 11 Kasım 1938, s. 3. 
George Benneb ise Atatürk ile yaşadığı bir anısını anlatırken yine O'nun barışçı politikasından bahsederek; “Atatürk'ün karakterinin bir cephesini göstermek itibariyle bir noktayl hatırlatmak isterim. Bize savaşlardan birini anlattyordu. Birden bire durdu: 'Görüyorsunuz ya, dedi, birçok zaferler kazandım. Fakat bunların en büyü̈̆̈̈nden sonra bile her akşam, savaş alanlarında ölen bütün askerleri düşünerek içimde derin bir keder duyuyorum'. Cesaret ve zekâsından başka yüreği bu kadar âlicenap olan böyle bir liderin, yurdu için mucizeler yaratmıș olmasına șașılabilir $m i{ }^{\prime \prime 66}$ demiştir. Ulus gazetesinin verdiği bu haberle dünyanın diğer ucundaki bir ülkenin O'na bakış açısını öğrenmenin de ötesinde Türklerin ne kadar insancıl ve merhametli bir millet olduğunu göstermesi açısından da önemli olduğunu öğreniyoruz.

Hans Froembogen ise Western Mail gazetesinde Atatürk'le ilgili olarak; "Büyük harp birçok şöhretlerin meydana çıkmasına veya ölmesine sebep olmuştur. Fakat bu umumi felaketin el uzatmadı̆̆ şöhretler arasında beynelmilel bir mevkie yükselen ve bilhassa bundan sonra dünya nazarındaki prestijini tamamen yükseltenlerin en başında gelen ve bunların en şayan-l dikkati olan, şüphesiz ki, modern Türkiye'nin kurtarıcısı olan Gazi Mustafa Kemal'dir" ${ }^{\prime 87}$ yorumunu yapmıs ve O'nu uluslar arası bir statüye yükseltmiştir.

Herbert Melzig ${ }^{88}$ ise Mustafa Kemal'den bahsederken, O'nun kimliğinin Nil sahillerinden eski Çin Denizlerine kadar uzanan bir efsane olduğunu söyleyerek, gerek zekâsı ve gerekse kuvvetiyle hem kendi milleti ve bütün dünya için bir dâhinin neler yaratabileceğini göstermesi bakımından büyük bir lider olduğunu ifade etmiștir ${ }^{89}$. Ulus gazetesinin verdiği bu haberin haricinde Herbert Melzig ayrıca yazdığı kitabında da onun için; "Avrupa'nın bazı muharrirleri, Mustafa Kemal'in Samsun'a ayak basmast ile başlayıp Lozan Muahedesi'nin imzalanmaslyla sona eren istiklal mücadelesine 'Türk Harikasl' adını verdiler. Osmanlı Devleti'nin cihan harbi sonunda ne vaziyette bulunduğu ve 1918-1922, dört yll içinde Anadolu'da cereyan eden hadiseler hatırlanarak göz önüne getirilecek olursa, insanin bunu hakikaten harikadan başka bir türlü ifade etmesine imkân yoktur" dedikten sonra O'nun Türk tarihi alanında gerçekleştirdiklerine de değinerek; "Atatürk, Türk milletine kendi milli tarihini ögrretmeye başlamakla, esasen malum olan bir tarihi yeni bir ışık altında göstermeye teşebbüs etmemiştir. $O$, Türk tarihinin meçhul kalmış ve Osmanlı hâkimiyeti devrinde tetkikine hiç heves edilmemiş olan, İslamiyet'ten önceki fasıllarını açmıştır... Mustafa Kemal, Türk tarihinin

${ }^{86}$ George Benneb, "Ecnebi Gözüyle Atatürk”, Ulus, 11 Kasım 1938, s. 3.

${ }^{87}$ Hans Froembogen, "Ecnebi Gözüyle Atatürk", Ulus, 11 Kasım 1938, s. 3; Yabancı Gözüyle Cumhuriyet Türkiyesi, s. 64-65.

${ }^{88}$ Herbert Melzig bir Alman tarihçisi olarak, Osmanlı ve Türk tarihi ile ilgilenmis ve "Atatürk" adlı 300 sayfalık bir kitap yazmış olup, bu kitap, Atatürk'ün eşsiz şahsiyeti ile O'nun eseri olan Türk Milli Mücadelesini ve Türk inkılâbını anlatmaktadır. Bkz. Yabanct Gözzüle Cumhuriyet Türkiyesi, s. 64-65.

${ }^{89}$ Herbert Melzig, "Ecnebi Gözüyle Atatürk", Ulus, 11 Kasım 1938, s. 3. 
meçhul fasıllarını bu günkü politika savaşı için tarihi haklar bulmak maksadıyla açmış değildir. $O$, halkını yalnız milli şuuruna çağırmıştır... Kendisi bizzat Asya tarihinin yeni bir faslını yazdırmış ve emperyalist Avrupa'nın cihan tarih telakkisini reddetmiștir... Atatürk, Türk tarihinin tetkikleriyle, Türk milletine yeni ve modern ilim usullerine dayanan bir tarihin milli kuvvetin yalnız genişliğini de ğil aynı zamanda hudutlarını da gösterdiğini ögrretmiştir... Yeni Türkiye, Atatürk ile yalnız İslam telakki ve görüslerini değil, aynı zamanda Avrupa'nın siyasi düşünme tarzını da aşmıştır. Türkiye Cumhuriyeti, cihanın gürültülü politika tezahürleri içinde sakin bir kutup ve sığınak olmuştur. Bu politikanın kendinden evvelkine benzer tarafi olmadı ̆̆ gibi, taklidi de yoktur. Atatürk, Türk milletine benliği ve kudretinin hudutların tanıttı... Türkiye, evvelce Osmanlı Devleti aleyhinde ayaklanmış olan bütün Balkan milletlerini hakiki kardeşlik ve dostluk bağlarıyla birleştirdi $\imath^{90 "}$ yorumunu yaparak onun daha önce çok fazla bahsedilmemiş bir özelliğini hatırlatmıştır ${ }^{91}$.

\section{E-Polonya'daki Akisler}

Polonya gazeteleri de, Atatürk'ün ölüm haberine oldukça geniş yer ayırmış, gece yayınladıkları nüshalarla bu acı haberi ilk sayfalarında neşrederek, Türk milletinin büyük kederine iştirak etmişlerdir. O'nun hakkında yazdıkları yazılarda, Atatürk'ün yeni Türkiye'yi yaratması olayını Washington'un Birleşik Amerika'yı yaratmasına benzeterek yeni Türkiye'nin tarih sahnesine çıkmasının milletlerarası arenada önemli etki yapacağını belirtmişlerdir. O'nun hayatını yazarken elde ettiği eserin büyüklügünü ve faaliyetinin muazzamlığını özellikle vurgulamış, Atatürk'ü efsanevi bir insan olarak vasıflandırmışlardır ${ }^{92}$.

Yarı resmi Poiska (Polska) gazetesi, Atatürk'ün vatanperverliğini ve askeri dehasını ön plana çıkaran yazılar yazdı̆̆ını Cumhuriyet ve Akşam

90 Yabancı Gözüyle Cumhuriyet Türkiyesi, s. 66-74; Herbert Melzig ayrıca "Türklerce bilindiği gibi, bir gün bütün dünyaca anlaşılacaktır ki, yüzyılımızın gerçek önderi Atatürk'tür" sözünü çok kullanmış ve bütün yazılarında bu gerçeği dile getirmiştir. Bkz. İlgazi, a.g.m., s.428.

1938 Haziranında Türkiye'yi ziyaret etmiş olan Mr. King de Herbert Melzig ile aynı duyguları paylaşmaktadır. New-York şehrinin tanınmış ekonomistlerinden olan King yaptığı ziyaretinden sonra bizzat şu ifadeyi kullanmıștır; "Bu günkü Türkiye biz Amerikalılara varmak istediğimiz gaye için klymetli ilhamlar veren bir numunedir".

Onunla aynı duyguları paylaşan diğer bir Amerikalı da The National Geographical Magazine Mecmuası adına Türkiye'yi ziyaret eden Sendler olmuştur. Şendler, ziyaretinden sonra Türkiye ve Atatürk hakkındaki intibalarını şöyle anlatmaktadır; "Türkiye'de bir etüt yapma emrini aldığım zaman bu teklifi biraz tereddütle ve biraz da isteksizlikle karșıladım... Tamamıyla yabancı bir zihniyetle karşılasacağımı tahmin ederek faydalı bir temas yapabileceğimi ummuyordum. Hakikat tahayyüllerimden ne kadar farklt imiş. Temas ettiğim bu insanlarla kendi aramda daima müsterek bir sempati ve mütekabil bir anlasma buldum... Atatürk'e karşı duyulan minnettarlık ve sonsuz muhabbet hisleri bütün Türk milletini bir vücut halinde toplamış ve onu zeval bulmaz bir itila yoluna sokmuştur. Bütün dünya Kemalist Türkiye'nin elde ettiği genis muvaffakiyetleri öğrenmelidir. Türkiye hakkında yazacă̆ım makale bütün Amerikalilar tarafindan okunacak ve Türkiye'yi herkes tanıyacak" Bkz. "İki Amerikalı Türkiye'de Gördüklerini Hayranlıkla Anlatıyorlar”, Ulus, 2 Haziran 1938, s. 5.

${ }^{92}$ Gazeteler, Mustafa Kemal Atatürk daha hayatta iken bile isminin bir efsane olduğunu yazmışlardır. "Ulu Önderimizin Vefatı Bütün Cihana Derin Bir Heyecan ve Teessür Verdi", Tan, 12 Kasım 1938, s. 9. 
gazetelerinin verdiği haberlerden öğrenmekteyiz. Gazete özellikle O'nun muharebe meydanlarındaki zaferlerine değinerek, bu zaferlerin millet hayatında yeni bir sayfanın açılmasına yol açtığını belirtmiştir ${ }^{93}$.

Kurjer Poranny gazetesi, Atatürk'ün Milli Mücadeleden sonra milletinin hayatındaki başlıca rolüne değinerek, yeniden bir ülke yaratmasını ince ayrıntılarıyla verirken, aynı duyguları paylaşan Kurjer Varzawski gazetesi ise şunları yazmıştır; "Uzun bir yol kat edilmiştir. Azametli bir eser vücuda getirilmistir. Bütün bunlar Atatürk'ün eseridir"'94 diyerek bu eserlerin gelecekte örnek alınması gerektiğini vurgulamıștır. Ploska Zbrojan gazetesi ise özellikle Latin alfabesinin kabulü üzerinde durarak, O'nun medeniyete yaptığı hizmetleri anlatmıştır ${ }^{95}$.

Goniec Warzawski'nin Atatürk'ün vefatı dolayısıyla büyük eserinden bahseden yazısına dair verdiği haberinde Kurun gazetesi; "Atatürk'ün ölümü enternasyonal mahiyette bir hadisedir. Atatürk, 15 sene içinde, Türkiye'yi modern bir devlet yapmıstır. Türk ordusunu islah etmis ve Balkanların Yakın-Doğu'nun en kuvvetli ordusu haline getirmiştir. Hâkim dış politikası sayesinde Türkiye, dünya politikasında çok önemli bir unsur olmuştur" 16 sözleriyle Türkiye'nin gelecekteki hâkim rolünü de ifade etmiştir. Illustrovvany Kurjer Codzienny'de aynı duyguları paylaşarak onun için şunları yazmaktadır; "Atatürk Türkiye'yi, silah kuvvetiyle kurtarmış ve Washington'un Birleşik Amerika'yl yaratması gibi yeni Türkiye'yi yaratmiştır. Atatürk'ün eseri hatta beynelmilel büyük işlerde de tesirini göstermiştir" ${ }^{\text {"97 }}$.

Polska gazetesinin de yaptığı yoruma dair Akşam ve Ulus gazeteleri verdikleri haberinde; "Atatürk yeni Türkiye'yi kılıç ile meydana getirmiş ve dehası ile tensik etmiştir. Onun yaratıcı ruhunun ve hararetli vatanseverliğinin harekete geçmemiş olduğu hiçbir saha yoktur. Eski Türkiye'nin bütün felaketlerinin kaynağı Osmanlı Devleti'nin dâhili işlerine ecnebi devletlerin müdahale etmelerine cevaz veren sultanlar rejimi olduğunu anlayan ilk adam olmuştur. Atatürk Türkiye'yi hicaptan ve taksime uğramaktan kurtarmıştır. Hali hazırda Türkiye hem kendi yakınında hem de bütün Avrupa'da birçok dostlara maliktir. Bütün dünyanın hayranlığını celbeden, Atatürk Türkiyesi olmuştur",98 dedikten sonra Lozan Antlaşmasından da bahsetmiş ve bu antlaşmayı, diğer devletlerden önce

93 “Dünya'nın Büyük Kaybı”, Cumhuriyet, 12 Kasım 1938, s. 5; "Büyük Matemimizin Hariçteki Akisleri”, Akşam, 13 Kasım 1938, s. 7; Ayın Tarihi, Kasım 1938, s. 181.

94 "Büyük Matemimizin Hariçteki Akisleri", Akşam, 13 Kasım 1938, s. 7; "Hariçte Duyulan Derin Teessürler", Tan, 13 Kasım 1938, s. 9; "Dünya'nın Büyük Kaybı", Cumhuriyet, 12 Kasım 1938, s. 5; Ayın Tarihi, Kasım 1938, s. 181.

95 "Atatürk ve Dünya Matbuatı", Cumhuriyet, 14 Kasım 1938, s. 7.

96 "Dünya Matbuatının Neșriyatı", Kurun, 14 Kasım 1938, s. 4; Ayın Tarihi, Kasım 1938 , s. 181

97 "Ulu Şefimize Dünya'nın Hayranlığı”, Tan, 16 Kasım 1938, s. 7 ; “Atatürk Türkiye'yi Kılıcı ile Meydana Getirmiștir", Aksam, 15 Kasım 1938, s. 2.

${ }_{98}$ "Büyük Yasımıza İştirak Edenler", Ulus, 15 Kasım 1938, s. 5; “Atatürk Türkiye'yi Kılıcı ile Meydana Getirmiştir”, Akşam, 15 Kasım 1938, s. 2. 
Türkiye'ye yüz elli yıldan beri ananevi dostluklarla bağlı olan Polonya'nın kabul etmiş olduğunu söylerken Türkiye'nin artık bundan sonra uluslararası siyasette hesaba katılması gereken bir unsur olduğunu da vurgulamıştır. Hatta, Osmanlının hasta adamının artık iyileştiği ve eski enerjisini geri kazandığı ve bu mucizeyi de Atatürk'ün başardığını belirtmiştir.

Diğer yandan Ankara Büyükelçisi Sokolniski, Exspress Poranny gazetesine verdiği demecinde, Türkiye'nin Atatürk'ün idaresi altında yeniden Yakın-Şark'ta bir anahtar görevini üstlendiğini, siyasi sahada ise Doğu Avrupa'da denge sağladığını ve dünyanın bu kısmında yaşayan milletlerin bağımsızlıklarını muhafaza edeceğini söylemiştir ${ }^{99}$.

Kopenhag Nasyonal Tidende gazetesi de aynı övgülere yer vererek Atatürk'ün politikasının tarihte büyük bir örnek olarak kalacağını yazmış ve kendisini XX. yüzyılın en büyük hakikatini yaratan adam olarak nitelendirmiştir. ${ }^{100}$

Barselona-Vansuar gazetesi ise, Atatürk'ten Sakarya'nın gazisi, İzmir'in fatihi olarak bahsetmiş ve tarihte en çok hayranlığa layık örneklerden biri olarak onu kabul ettiklerini yazmıştır. Ayrıca O'nun yapıcı ve barış̧̧ı eserine olan hayranlıklarını belirterek şu cümlelere yer vermiştir; "Inkısama uğramış, tezlil edilmiş, ihtizar haline getirilmiş olan Türkiye'yi kuvvetli ileri ve mütecanis bir millet haline getiren adam ölmüstür. Tarihte en ziyade hayranlığa layık kişi olarak askeri deha devlet adamı ve filozof ölmüştür"101.

\section{F- İtalya ve İspanya'daki Akisler}

Büyük kayıp İtalya'da da geniş yankı uyandırmış, bütün İtalyan gazeteleri de çağdaşı Avrupa basınıyla aynı görüşleri paylaşmış, büyük liderin hayatını, bütün mesaisini ve yeni Türkiye'nin inşası için olan mücadelelerini anlatırken onun büyüklüğünden bahsetmişlerdir. Mussolini'nin gazetesi Atatürk hakkında geniş bir makale neşrederken, diğer bütün İtalyan gazeteleri de aynı şekilde olaya yer vermişlerdir. Yayınlanan bu makalelerde Atatürk'ün hayatından, faaliyetlerinden ve yeni Türkiye'yi yaratan mücadelelerinden bahsedilmiş olduğunu Türkiye'deki gazetelerden haber almaktayız.

Mussoli'ni tarafından kurulmuş olan Popole d'Italia gazetesi şu satırlara yer vermiştir; "Atatürk hayatının son yirmi senesini Türkiye'de muazzam yapıcı faaliyete hasretti. Bu faaliyet şimdi çok yüksek ve să̆lam

9) “Atatürk Türkiye'yi Kılıcı ile Meydana Getirmiştir”, Akşam, 15 Kasım 1938, s. 2; "Büyük Yasımıza İstirak Edenler”, Ulus, 15 Kasım 1938, s. 5; "Atatürk-İnönü ve Cihan Matbuatı", Cumhuriyet, 15 Kasım 1938, s. 4; "Atatürk'ün Ölümü Karşısında Dünya Matbuatı", Kurun, 15 Kasım 1938, s. 2; "Ulu Şefimize Dünya'nın Hayranlığı", Tan, 16 Kasım 1938, s. 7.

100) "Hariçteki Akisler", Tan, 21 Kasım 1938, s. 4; "İspanyol Matbuatında", Kurun, 20 Kasım 1938, s. 9.

01 "İspanyol Matbuatında", Kurun, 20 Kasım 1938, s. 9; "Hariçteki Akisler", Tan, 21 Kasım 1938, s. 4. 
bir halde görünen eserler verdi. Ölüm bu vatan babasını en cevval bir zamanında yakalamıştır". Gazete ayrıca Atatürk'ün askeri hayatını, inkılâpçı faaliyetini, politikaya dönüşünü, dünya harbindeki önemli askeri başarılarını, Gelibolu müdafaasını ve harpten sonra Türk ordusunun kurulmasını hatırlattıktan sonra özellikle Milli Müdafaa Kanunu, Harf İnkılâbı, İtalya ve İsviçre kanunlarından alınan Ceza Kanunu ile Medeni Kanundan bahsederek İnkılaplarını uzun uzadıya büyük bir övgü ile anlatmıştır ${ }^{102}$.

Corriera Della Sera gazetesi ise, Atatürk'ten, Türkiye'de yeni bir zihniyet yaratan adam olarak bahsedip Montrö'deki Boğazlar meselesinin halledilmesindeki siyasi başarısını ön plana çıkarmıştır. Gazela Del Popolo gazetesi de Atatürk'ün zihniyetiyle sultanların zihniyeti arasındaki tezatı ortaya koymuş, Messagero gazetesi ise dünya harbinin sonunda Türkiye'de kalan tek gerçeğin Kafkasya ile Akdeniz arasında büyük bir bütün oluşturan Türk milleti olduğunu hatırlattıktan sonra Atatürk'ün yabancı müstevlilere karşı muzaffer kıldığı gerçeğin de aynı gerçek olduğunu kaydetmiştir. Çökmüş bir memlekete eski mazisinin kahramanlığını yeniden iade eden Atatürk'ün sadece bu icraatının bile O'nun adını yüceltmeye yeterli olduğunu belirtmiş ve diğer bütün İtalyan gazeteleri de aynı ifadeleri kullanmışlardır ${ }^{103}$. Tribun gazetesi, Atatürk'ün ölümüyle, Yakın-Doğu'nun ilerlemesini birinci derecede sağlayan kişinin de kaybedilmiş olduğunu yazmışıır' ${ }^{104}$.

Cenaze merasiminde ise İtalyan hükümetini temsil etmek üzere, İtalya'nın eski Ankara Büyükelçisi Baron Alloizi görevlendirilmiştir. Alloizi, Ankara'ya gelişinde gazetecilere verdiği demecinde; "Ankara'da sefir bulunduğum zamandan beri Atatürk'ü pek yakından tanıdım $O$ pek büyük bir insandl. Ölümü karşısındaki üzüntüm çok derin ve büyüktü̈r" ${ }^{105}$ demiştir.

Atatürk'ün ölümü İspanya'da dahi büyük bir etki yapmış, Barselona'nın en büyük gazetesi olan Vanguardia gazetesi, $11 \mathrm{Kasım}$ tarihli nüshasının birinci sayfasında, büyük liderin vefatı haberini verdikten sonra birde büyük boy bir fotoğrafını yayınlamıştır. O'nun için yazdığı makalede, diğer Avrupa gazeteleri gibi, O'nun yapıcı ve barış̧̧ı eserinden büyük bir hayranlıkla bahsederek şu cümlelere yer vermiştir; "İnkısama uğramış, tezlil edilmiş, ihtizar haline getirilmiş olan Türkiye'yi kuvvetli, ileri ve mütecanis bir millet haline getiren adam ölmüstür. Sakarya'nın gazisi, müstevlilerin galibi ve İzmir'in Fatih'i, tarihte en ziyade hayranlığa layı numunelerden

102 "Yirmi Yıllık Muazzam Yapıcı Faaliyet", Akșam, 14 Kasım 1938, s. 2; "Atatürk ve Dünya Matbuatı”, Cumhuriyet, 14 Kasım 1938, s. 7; “Atatürk'ün Ölümü Karşısında Dünya Matbuatı", Kurun, 15 Kasım 1938, s. 2; Ayın Tarihi, Kasım 1938, s. 177. 1938, s. 177 .

104 "B̈̈̈lo Yasimiza İşirak Edenner", Ulus,

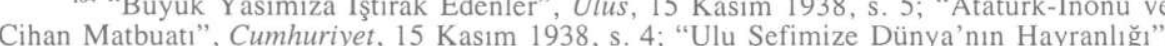
Tan, 16 Kasım 1938, s. 7.

ıos "Çankaya'daki Güneş", Akşam, 20 Kasım 1938,s. 3. 
biri olarak kendini gösterecektir. Kendisi nefsinde askeri deha ile devlet adamı ve filozof dehasın bir araya getirmiştir ${ }^{106}$ " diyerek O'na tarihteki yerini vermiştir.

\section{G-Hollanda ve Belçika'daki Akisler}

Akşam gazetesinin verdiği habere göre, bütün Hollanda gazeteleri, Atatürk'ün ölüm haberine oldukça geniş yer ayırmış, hemen hemen bütün gazeteler ilk sayfalarında O'nun hayatını anlatmışlardır. Ayrıca, Hollanda Radyosu da O'nun hayatı hakkında yayınlar yapmışıı' ${ }^{107}$.

Belçika'da ise gazetelerin, O'nun biyografisini ve fotoğraflarını yayınlayarak hayatı ve büyük rolü hakkında uzun açıklamalarda bulunduklarını Akşam gazetesinin verdiği haberden öğrenmekteyiz. Soir gazetesi, özellikle Lozan Antlaşması'nın önemini vurgulamış, Atatürk'ün olağanüstü ıslahat ve inkılâplarından bahsederek, bu inkılâpların son derece büyük olduğunu ve bu büyüklük karşısında dünyanın hala hayret içerisinde bulunduğunu yazmıştır ${ }^{108}$. Nation Belge gazetesi ise, O'nu, milletini her bakımdan kurtaran çok büyük bir devlet adamı olarak tanımlarken Independance Belge gazetesi ise O'nu zamanın en azimkâr ve yılmaz inkılâpçısı, milletine bir millet şuuru veren kişi olarak vasıflandırmıştır. Yazdığı makalenin sonunda, O'nun büyük eserinin bundan sonra da devam ettirilmesinin önemine değinerek bu hususun özellikle Türkiye ve Avrupa adına çok önemli olduğunu ifade etmiştir. ${ }^{109}$

Peuple gazetesi ise, büyük lideri yeni Türkiye'nin enternasyonal vaziyetini takviye eden ve Sovyet Rusya ile sıkı dostluk ilişkileri tesis eden ilk Türk devlet adamı olarak tanımlamıştır. Libre Begique gazetesi ise Atatürk'ün hayatını anlattıktan sonra, O'nun sayesinde Türkiye'nin uluslar arası statüsünün, prestijinin ve otoritesinin yükseldiğini belirttikten sonra; "Atatürk kadar milletine bu kadar az zamanda bu derece büyük hizmet eden devlet adamı yoktur ${ }^{110 "}$ " diyerek O'na hak ettiği değeri vermiştir. Ayrıca, Belçika Parlamentosu, 16 Kasım 1938 günkü toplantısında, Atatürk'ü anma programı düzenlemiş, meclis başkanı, mebusları ayağa kalkmaya davet ederek, O'nun hakkında bir söylev vermiştir ${ }^{111}$.

\section{H-C Cekoslovakya ve Finlandiya'daki Akisler}

Bütün Çekoslovakya basını, O'nun meziyetlerinin kıymet biçilemeyecek kadar yüksek değerde olduğunu ve Türkiye'ye uluslararası sahada birinci planda bir mevki kazandırdığını yazmıştır. Bilhassa

${ }^{106}$ Ayın Tarihi, Kasım 1938, s. 181.

107"Her Taraftan Büyük Matemimize İsstiraḱ Ediliyor", Akșam, 12 Kasım 1938, s. 2.

108 "Her Taraftan Büyük Matemimize Iş̧tirak Ediliyor", Akşam, 12 Kasım 1938, s. 2.

${ }^{109}$ Ayın Tarihi, Kasim 1938, s. 182.

${ }^{110}$ Ayın Tarihi, Kasım 1938, s. 182.

III “Belçika Parlamentosunda Büyük Şef Atatürk'ün Hatırası Tebcil Edildi”, Ulus, 17 Kasım 1938, s. 3; Cenaze merasiminde ise, Belçika Kralı'nı fevkalade murahhas sıfatıyla Belçika'nın Türkiye'deki eski elçisi Roymond'un temsil etmesi, ayrıca maslahatgüzar Rothe'nin de heyete dâhil olmasına karar verilmiştir; BKz. Akşam, 18 Kasım 1938, s. 7. 
Atatürk'ün gerçekleştirdiği inkılâplarla Türkiye'yi kuvvetlendirdiğini ve modernleştirdiğini belirtmişlerdir. Ceska Slova gazetesi O'nu, yeni Türkiye'ye ruh veren adam olarak algılayıp böylesine yüksek derecede bir lidere sahip olduklarından dolayı da Türklere gıpta ettiklerini açıkça ifade etmiş ve şöyle demiştir; "Çünkü bizde bugün Mustafa Kemal'in dünya sahnesinde göründü̆̆̈̈ zamandaki Türkiye'nin vaziyetine benzer bir mevkide bulunmaktaylz. Atatürk, Türkiye'yi İngiliz parlamentarizm modeli üzerinden bir devlet yapmıs ve memleketinde kuvvetli bir sanayi yaratmıştı. Müslümanlık âleminde bir mucize manzarası arz etmektedir ${ }^{112, "}$. Bu cümlelerle Çekoslovakya'nın Atatürk'ü ve O'nun başarılarını örnek aldığını Cumhuriyet gazetesinin verdiği haberden öğreniyoruz.

Lidove Novini gazetesi, Atatürk'ün savaştan sonraki âlemin en kıymetli simaları arasında yer aldığını, O'nun yapıcı karaktere sahip olan büyük bir vatansever ve demirden iradenin timsali olduğunu belirtmiştir. Ayrıca, Türkiye'nin yeniden doğuşunun modern tarihin en büyük olaylarından birisi olduğunu da vurgulamıştır. Lidove Listy gazetesi ise, O'nu, Türk tarihinin en büyük siması olarak belirtirken Bohemia gazetesi de arkasında gelecekten korkmayan bir milli devlet bırakan adam olarak vasıflandırmış, Prager Tageblat gazetesi, Türkiye'nin O'nun idaresi altında tamamen yenilenmesiyle, dünya politikasında önemli bir rol oynayacağını belirtmiştir ${ }^{113}$.

Finlandiya basını da diğer Avrupa gazeteleri gibi Atatürk için geniş sütunlar ayırmışlar, Svenska Pressen, başmakalesinde; "Bütün liderler arasında Atatürk, memlekette vücuda getirdiği inkllâp eserlerinin büyüklüğ̈̈ bakımından, çok önemli bir mevki işgal etmektedir" diyerek onun uluslar arası alandaki rolünü ifade ederken aynı zamanda hayranlıklarını da belirtmekten geri kalmamıştır. Hufvud Stadbladet gazetesinde çıkan bir yazıda da; "Atatürk fevkalade bir devlet adamı, harp sonrası dünya tarihinin en önemli simalarından birisi idi. Atatürk olmasa idi yeni Türkiye mevcut olamazdl $^{1 / 4}$ " denilmektedir.

Helsingin Sanomat gazetesi ise Atatürk için şu yorumu yapmıştır; "Atatürk zamanımızın büyük devlet adamları arasında çok büyük bir mevkie maliktir. Askeri meziyetleri ve memleketinin inkılâbı içindeki muazzam mazisi çok büyüktür. Atatürksüz Türkiye, büyük bir devlet olamazd»"115.Uusi Suomi gazetesi de aynı şekilde ondan büyük inkılâpçı olarak bahsettikten 1938, s. 180.

112 “Atatürk ve Dünya Matbuatı”, Cumhuriyet, 14 Kasım 1938, s. 7; Ayın Tarihi, Kasım

113 “Atatürk ve Dünya Matbuatı", Cumhuriyet, 14 Kasım 1938, s. 7; Bohemia Gazetesi ise, onun için arkasında istikbalden korkmayan, kuvvetli, milli bir devlet bırakan adam olarak bahsetmiştir. Bkz. Ayın Tarihi, Kasım 1938, s. 180.

114 "Büyük Yasımıza İştirak Edenler", Ulus, 15 Kasım 1938, s. 5 ; “Atatürk’ün Vefatı ve Dünya Matbuatı”, Cumhuriyet, 16 Kasım 1938, s. 2; Ayın Tarihi, Kasım 1938, s. 182-183.

is "Finlandiya Gazeteleri Neler Yazıyor", Kurun, 14 Kasım 1938, s. 4; "Büyük Yasımıza İştirak Edenler”, Ulus, 15 Kasım 1938, s. 5; “Atatürk'ün Vefatı ve Dünya Matbuatı", Cumhuriyet, 16 Kasım 1938, s. 2. 
sonra, Atatürksüz Türkiye'nin büyük bir devlet olamayacağını belirtmiştir ${ }^{116}$.

Albert Saro, Parl Suvar gazetesinde yazdığı bir makalede O'nun kahramanlığı ve dehasından bahsederek, Atatürk'ün kendisi için sadık ve dürüst bir dost olduğunu, O'nun barıșı korumadaki büyük çabasının dünya barışı için büyük bir kayıp olduğunu söyleyerek O'na olan hayranlığını ifade etmiştir ${ }^{117}$

\section{J-İsveç ve Ísviçre'deki Akisler}

İsveç basını, Atatürk'ün ölümü münasebetiyle, hayatı ve șahsiyeti hakkında makaleler yayınlamışlardır. Cumhuriyet gazetesi Aftonbladet gazetesinde yer alan habere bağlı olarak; "Türkiye'nin yeniden oluşturulmast ve tanzimi keyfiyetinin hayret verici tam bir inkılâp" olduğunu belirttikten sonra, "Son padişah toprağını terk ettiği vakit 1922 Teşrin-i sanisinde elde edilmiş olan nihai zafer bütün șarkta sevk ve meserretle selamlanmıștır. Bunu takip eden hareketler, kararlardaki emniyet ve icradaki surat itibariyle bütün dünyayı hayrete gark etmiştir" diyerek onun büyük zaferi karşısında duydukları hayranlığı gizleyememişlerdir. Goeteborg Handels gazetesi ise O'nun devlet kuruculuk özelliğine değinerek diğerlerinden farklı olarak, Osmanlı Devleti'nin bakayası içinden milli Türk Devletini kurduğunu, ziraatı sistematik bir şekilde rasyonelleştirmek suretiyle iktisadi hayatı geliştirdiğini yazmıştır ${ }^{118}$.

Akșam gazetesinin verdiği habere göre Svenoka Dagbladet gazetesi de Atatürk'ün müstevlilerin boyunduruğunu kırdığından bahisle Türk vatanını parçalanmaktan kurtardığını, kısa zamanda bütün dünyanın dikkatini çektiğini ve devletlerin Türkiye ile ilişki kurmak istediklerini ortaya koymuştur ${ }^{119}$. Nya Daglight Allehanda gazetesi ise Atatürk'ün kurmuş olduğu eserinin on dört yılda dünya tarihinde çok derin izler bıraktığını söyleyerek Türklerin, Atatürk'ün sayesinde büyük bir gelişme gösterdiklerini ve bundan sonra da bu gelişmeyi devam ettireceklerini belirtmiştir. ${ }^{120}$

Social Demokraten ve Dagens Nyheter gazeteleri de aynı hususa vurgu yaparak, Türkiye'nin Atatürk'ün idaresi altında modern bir devlet olduğunu ve uluslararası itibarının gittikçe arttığını özellikle dış politikada büyük başarılar kazandığını belirterek O'nun I. Dünya Savaşı sonrasında devlet başkanları arasında en dikkate değer kişi olduğunu, önce Türkiye'yi kurtarıp

116 "Büyük Yasımıza İștirak Edenler", Ulus, 15 Kasım 1938, s. 5; Ayın Tarihi, Kasım 1938 , s. 183

117 "Alber Saro, Bu Ziya Sulh Davası İçin de Çok Elimdir", Ulus, 11 Kasım 1938, s. 3.

118 “Atatürk ve Dünya Matbuatı”, Cumhuriyet, 14 Kasım 1938, s. 7; Ayın Tarihi, Kasım 1938, s. 184

119 "Türkiye Atatürk'ün Kuvvetli Şahsiyetine Ayrılmaz Bir Şekilde Bağlıdır", Akșam, 14 Kasım 1938, s. 6.

120 "Büyük Yasımıza İştirak Edenler", Ulus, 15 Kasım 1938, s. 5; Ayın Tarihi, Kasım 1938, s. 184 
daha sonra yeni bir Türk devleti yarattığını, memlekete yeni bir anayasa, yeni bir kültür, yeni bir ülkü verdiğini yazmışlardır. Ayrıca dünyanın hiçbir zaman Türkiye'nin batı zihniyeti içinde yeniden kurulması gibi heyecanlı bir drama asla şahit olmadığını da ifade etmiştir ${ }^{121}$.

Stokholms Tidningen gazetesi de, Atatürk'ün yalnız memleketinin hâkimi değil, bir devlet adamı olarak mükemmel bir teşkilatçı olduğunu da söylemiştir. Noye Zürher Saytung gazetesi, Atatürk'ü büyük bir medeniyet kaynağı olarak kabul edip, O'nun Türkiye'yi Batılılaştırmaktan ziyade, milletin müdafaası, geleceği ve ilerlemesi için ona hayat olarak gerekli olan unsurları vermek istediğini belirtmiştir. Ayrıca O'nun, Türkiye'yi Batı ile Doğu arasında bir köprü durumuna getirerek, bu politika sayesinde hiç kimsenin artık O'na saldırmaya cesaret edemeyeceğini söylemiştir ${ }^{122}$.

Frankfurter Saytung gazetesinin Atatürk için yazdığı başmakaleye dair Ulus gazetesinin verdiği habere göre, gazete Atatürk'ün inkılâpçı yönünü ön plana çıkararak; "Anadolu'nun, asil anayurdun milli şuurundan doğan yeni ve gürbüz devlet, şarkın hasta adamı yerine geçen ve gerek içten ve gerekse diştan tahkim edilmiş olan cumhuriyet, onun eseri yalnız bir kişinin eseridir. Birçok inkulâplar geçirmiş olan devrimizde Türkiye'deki gibi derinlere kök salmış pek az inkılâp vardır... Can çekişen hilafetten ve Cihan Harbinin inhizamindan kendini kurtararak șurlu bir hareketle anayurdu Anadolu'ya çekilmiş olan Türkiye, bir ilerilik diyarl, Akdeniz'in şarkında ve YakınŞarkta barışın dayană̆ı olmuştur. Hızlı ve radikal bir surette yapılan inkılâp Atatürk'ün hayatından hiç farklı de ğildir. Bu inkılâbın çeşitli olan hatlarından hiç birini Atatürk'ün şahsiyetinden tefrik etmek imkânı yoktur. O'nun azim ve iradesi bu inkılâba daima hız vermis ve nihayet ilk cumhurbaşkanının fikirleri milletin malı olmuştur" diyerek Mustafa Kemal'in verdiği mücadelenin çok zorlu olduğunu, bu zorluklar karşısında sabırla ve bütün engelleri adım adım aşarak amacına ulaştığını söylemiştir. O'nun daha küçük yaşta iken babasını kaybetmesiyle "boynunun bükük kaldığını" da belirterek yazıya şöyle devam etmiştir; "Mustafa Kemal, 23 yaşında yüzbaşı olmuş, 1905'deki genç Türk ihtilalinde küçük bir grubu etrafina toplamıştı. Onlarla yaptığ görüşmeler daha o günlerde, vatanında çok radikal bir ıslahat yapılmasını arzu ettiğini göstermektedir. Bu tarihten itibaren $o$, düşüncelerinin gerçekleşmesi için mücadeleye girişmişti. Genç kurmay subay, kendine has olan askerlik kudreti ve ahlak metaneti sayesinde etrafindakilerin teveccühünü kazanmış ve birçok düşüncelerini onlara da kabul ettirmiştir".

Ayrıca, Trablusgap ve Balkan savaşlarındaki başarılarından da bahseden gazete, I. Dünya Harbi'ndeki rolüne de değinmiş ve devamla; "Osmanl Devleti harbe girmiş bulunduğu için ona, vatanına hizmet etmekten başka yapacak bir şey kalmamıştl. Mustafa Kemal memleketin içine serpilmiş olan asker ünitelerinden yeni bir tümen oluşturarak

${ }^{121}$ Ayın Tarihi, Kasım 1938, s. 184.

122 "Büyük Yasımıza İştirak Edenler", Ulus, 15 Kasım 1938, s. 5. 
Gelibolu'ya gelmiş ve birçok askeri başarıdan sonra generalliğe terfi etmişti. Anafartalar muzafferiyetini müteakip bütün memleket ona İstanbul'un kurtarıcısı gözü ile bakmıştır. Mustafa Kemal ile temas etmiş olan Alman subayları, onunla geçinmenin güç fakat onun temkinli ve birçok vesilelerle şecaat göstermiş olan cesur bir asker olduğunu anlattyorlardl. Ingiliz-Fransız müşterek taarruzu def edilirken, o en can alacak noktayl müdafaa etmişti. Mütarekeden sonra o tarihlerde Adana'da askerinin başında bulunmakta olan Mustafa Kemal düşmana kayıtsız şartsız teslim olunmasını şiddetle protesto etti. $O$, harbiye nazırı olmak, hükümeti kendi eline aldiktan sonra, Anadolu'da daha iyi şartlar altında ve daha büyük salahiyetlerle istiklal mücadelesine girişmek istiyordu. Çöküşten sonra da milli bir devlet kurmak ümidini kesmedi. Fakat İstanbul'u ikna etmek mümkün değildi. Padişah Ittilaf Devletlerine dayanmakla kendini daha ziyade emniyette görüyordu. Samsun'a çıktıktan sonra yeni devlet hakkındaki tasavvurlarını üç yıldan fazla gizleyen adam ancak Sakarya Zaferi'nden sonra asıl politik hedeflerine doğru ilk adımını atabildi..."

"Bütün bu işleri o, kudretinin bir sırr olan büyük bir sabır ve metanetle gerçekleştirdi... Yepyeni bir şekil alan kültür politikasından ilgisiz olan bütün unsurlar uzaklaştırıldl. Ekonomi yeniden organize edildi. Binlerce kilometre uzunluğunda demir yolu yapıldı. Yeni bir endüstri yaratıldı. Köye ve köylüye hatırı sayllır bir mevki verildi... Atatürk devletin mevkiini diş politikada da takviyeden geri kalmadl. Sovyet Paktı'ndan sonra Balkan Antantı, Sadabat Paktı'nı yaptı. Montrö Mukavelesiyle boğazlar üzerindeki

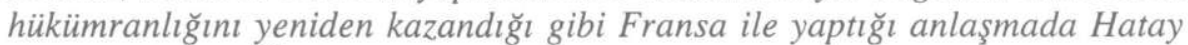
davasını halletti ${ }^{123}$ " demiştir.

Carel Hautman, Belfast Telegraph gazetesine yazdığ makalesinde, Atatürk'ü, sönmüş bir imparatorluğun küllerinden modern bir Türkiye'nin yaratıcısı olarak vasıflandırdıktan sonra, Türk milletine o zamana kadar görmediği büyük bir saadet getirdiğini de söylemiştir. Aynı şekilde, Raymond Cartier ${ }^{124}$ de, Le Nouvelliste gazetesine yazdiğ 1 makalesinde Atatürk'ü, Türkiye'nin ruhunu değiştiren hayal edilmesi dahi mümkün olmayan bir gelişme kaydeden bir kişilik olarak görmüştür ${ }^{125}$.

İsviçre basını da, 11 Kasım tarihinden itibaren Atatürk'e uzun makaleler tahsis etmiş ve O'nun dünya harbinden sonra bağımsız bir devlet yaratmak için verdiği mücadeleyi, bu mücadelenin arkasından yaratılan yeni devleti modernleştirmek için gerçekleştirdiği inkılâpları ve bu husustaki başarılarını yazmıştır. İnkılâplar içerisinde özellikle İsviçre Medeni Kanununun Türkiye'deki uygulamasına geniş yer verilmiştir. Bern'de çıkan Der Buno gazetesi onun için; "Türkiye'de serbest milli bir hayat kurmak için açtığı mücadelede hükümet ekseriya sert dini temayüllere karşı koymak

123 “Yeni Türkiye'yi Yaratan Büyük Adam Öldü”, Ulus, 17 Kasım 1938, s. 5.

${ }^{124}$ Fransız Edebiyatçı.

${ }^{125}$ Raymond Cartier, "Ecnebi Gözüyle Atatürk", Ulus, 11 Kasım 1938, s. 3; Yabancl Gözüyle Cumhuriyet Türkiyesi, s. 93-96. 
mecburiyetinde kalmıştır. Fakat artık bu devre tarihe karışmıştır" diyerek, laiklik alanındaki inkılâplarını ön plana çıkarmıştır.

Neue Zurcher gazetesi ise Atatürk'ü bir medeniyet kaynağ 1 olarak vasıflandırmış ve; "Türkiye'yi Avrupalılaştırmak değil fakat milletin müdafaası, istikbali, terakkisi için ona hayat olarak lazım olan unsurları vermek istiyordu. Atatürk aynı zamanda Türkiye'nin garp ile şark arasinda bir köprü olmasını istiyordu. Bu gün hiç kimse onun ıslahatçı eserine

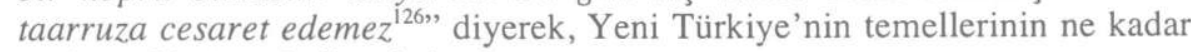
sağlam olduğunu belirtmiştir.

\section{K-Estonya, Letonya, Litvanya, Danimarka ve Norveç'teki Akisler}

Estonya'daki Ous Eesti gazetesi, Atatürk'ün Türkiye'de harikulade bir Rönesans başardığını, cesaretli bir dış politika takip ettiğini, Postimees gazetesi ise O'nun tarihi bir görevi yerine getirdiğini, Müslümanlık dünyasını modern medeniyete yaklaştırdığını, kadının sosyal seviyesini yükselttiğini yazmıştır. Pacevaleht gazetesi de, "Milletinin Hadimi ve Efendisi" başlığı altında yazdığı bir makalede Emil Ludwing'in eserinden bazı parçalar nakletmiştir ${ }^{127}$.

Letonya'daki bütün gazeteler de, Atatürk'ün ölümü dolayısıyla uzun makaleler neşretmişlerdir. Yarı resmi Briva Zeme gazetesi, tüm sayfalarını Atatürk'e ayırmış, özellikle "Asırları Aşan Adam" başlığı altında yazdığı makalesinde; "Atatürk zamanımızdaki devlet adamlarının en büyüğ̈̈ ve modern liderlik prensibinin en dikkate şayan mümessiliydi. $O$, tasvirine imkân olmayan bir inkilâpla millet ve devlet hayatında kuvvetli ve sağlam bir şahsiyet yaratılabileceğini ispat etmiştir. O, Avrupa'dan ayrı kalmış devletini, Avrupa seviyesine yükseltmiş ve ona modern bir devlet şekli vermistir. Bunların hepsi o kadar kısa bir zaman zarfinda olmustur ki, bunu evolüsyondan ziyade sıçrayış diye ifade etmek daha doğrudur ${ }^{128 "}$ " ifadelerini kullanmışır.

Jaunakas Zinas gazetesi ise, “Ankara'nın Büyük Kurucusu" başlığı altında Atatürk'ün biyografisini ve fotoğrafıyla birlikte O'nun eserinin ebedileşmiş olduğunu kaydederek bırakmış olduğu şeylerin Türkiye Cumhuriyetine her devirde millete gittikçe daha güzel ve daha mesut bir geleceğin kurulmasına imkân verecek olan en emin bir temel olacağına işaret etmiştir. Ayrıca Türkiye'de son on beş yıl içinde yapılan inkılâp hareketlerine değinen gazete, Atatürk'ün bağımsızlıkta gençliğe hayal bile edilmesine imkân olmayan bir hayat bağışladığını yazmıştır ${ }^{129}$. Ayrıca

\footnotetext{
${ }^{126}$ Ayın Tarihi, Kasım 1938, s. 180.

127 "Büyük Yasımıza İştirak Edenler", Ulus, 15 Kasım 1938, s. 5; "Atatürk-İnönü ve Cihan Matbuatı", Cumhuriyet, 15 Kasım 1938, s. 4.

${ }_{128}$ "Zamanımızdaki Devlet Adamlarının En Büyügüü Atatürk”, Akşam, 16 Kasım 1938, s. 4; "Bütün Dünya Onu Anıor", Kurun, 16 Kasım 1938, s. 9.

129 "Zamanımızdaki Devlet Adamlarının En Büyüğü Atatürk", Akşam, 16 Kasım 1938, s. 4; "Bütün Dünya Onu Anıyor”, Kurun, 16 Kasım 1938, s. 9; "Atatürk'ün Vefatı ve Dünya
} 
Latvijas Korelvisletu(Koreivisleta) adındaki ordu gazetesi de Atatürk'ün resmini basarak hakkında uzun makaleler yazmıştır ${ }^{130}$.

Litvanya basını henüz Atatürk ölmeden önce hastalığına dair İstanbul ve Ankara'dan gelen haberleri yayınlamaya başlamış ve ölümü üzerine daha geniş makaleler neşrederek, kendisini muasır devlet adamları arasında birinci sıraya yükselten inkılâplarını kaydederek O'nun Türkiye'ye yeni bir zihniyet ve medeniyet vermeğe muvaffak olduğunu yazmışlardır ${ }^{131}$. Yarı resmi Liotuvas Aidas gazetesi Atatürk için şu yorumu yapmıştır; "Atatürk faal bir hayat ile canlandırılmış olan milletinin yüreğinden yeni alevler fişkırtmıştır. Atatürk eskisiyle klyas kabul etmeyecek kadar yeni ve mükemmel bir devlet binası kurmuştur. Atatürk'ün faaliyeti bütün memleketin ruhuna girmiş, ona yapıcı hız vermiştir. Türkiye'nin birliği büyük ülkülere bağlı olan gençliği memleketin istiklali için birer zaman teşkil etmektedir. 15 sene sonra Atatürk muazzam bir hazine bırakmıştır. Bugün üniversitelere, her köyünde mekteplere, güzel sanatlar akademisine, konservatuara, gençlik teşkilatına sahip bulunan Türkiye'yi yeniden yaratmıştır. Memleket hayatında kadınlar önemli bir mevki sahibidirler. Deniz ticareti fevkalade kuvvetlendirilmiştir. Gazeteler, milletin bütün tabakalarl tarafindan okunmaktadır. Atatürk, Ankara'yı Türkiye'nin yeni hükümet merkezi olarak yeniden yapmış ve memleketine emsalsiz bir hazine bırakmıştır. Türk milletinin ruhu yenilenmiştir. Türkiye bütün dünyanin takdirine layıktır ve Avrupa milletler ailesi içinde şerefli Türkiye'nin nüfuzu büyüktür"132.

Danimarka gazeteleri de Atatürk ve eserinden hayranlıkla bahsetmişlerdir. Berlinske Tidende gazetesi, Atatürk'ü tarihte kahramanlık destanı yaratan kişi olarak tanımladıktan sonra devlet kuruculuğu ve inkılâpç1 yönleriyle ele alarak; "Atatürk, ömrünün en mükemmel çă̆ında iken ölmüştür. Fakat onun hayatındaki eseri, tarihte kahramanlığın destan olarak yaşayacaktır. Eserini o, bir muharip ve bir de devlet adamı olarak meydana getirmiştir. Kllıç sayesinde iktidar mevkiini kuranların birçoğundan tamamıyla farklı olarak, o zaferi kazandıktan sonra kılıcını kınına koymuştur. Atatürk'ün askerlik eserini iyice anlayabilmek için cihan harbinden sonraki Türkiye'nin vaziyetini hatırlamak lazımdır. Izmihlal olmuş bir devlet, hezimete uğramış bir ordu, bitkin ve yeis içinde bir millet. Buna rağmen Atatürk, karşısına çıkarılmış olan bütün orduları ezdikten sonra, Lozan'da 1923 Haziran'ında mağluplara milli Türkiye devletini dikte etmiştir. $O$, hudutların ç̧zmiş olduğu Türkiye'nin kendisine öncekinden daha büyük vazifeler yükleyeceğinin idrakindeydi. $O$, arkasında garplılaşmış bir modern devlet bırakmıştır. Şapka giymek, Arap harflerini atıp bizzat

Matbuatı", Cumhuriyet, 16 Kasım 1938, s. 2; "Ulu Şefimize Dünya'nın Hayranlığı”, Tan, 16 Kasım 1938, s. 7.

130 "Ulu Şefimize Dünya'nın Hayranlığı”, Tan, 16 Kasım 1938, s. 7; Ayın Tarihi, Kasım 1938 , s. 183.

${ }_{131}$ Ayın Tarihi, Kasım 1938, s. 183.

132 "Büyük Yasımıza İştirak Edenler”, Ulus, 15 Kasım 1938, s. 5; “Ulu Şefimize Dünya'nın Hayranlığı", Tan, 16 Kasım 1938, s. 7. 
hocalığını yaptığı yeni Türk harflerini kabul etmek gibi tamamıyla zevahirden sanilan yenilikler, Türklerde ezelden beri mevcut olan muharip ruhu bugünde yaşamasına rağmen kurulan yeni devlet, sulh politikasının en sağlam mesnedi olmuştur. Atatürk, Musul ve Hatay meselelerini halletmiş, memleket içinde enerjik bir surette ıslahat yapmıs, endüstri ve demir yolları kurmuştur ${ }^{133}$ " cümleleriyle Atatürk'ü anlatmıştır.

Social Democraten gazetesi ise, O'nun bütün devletlerin hiç beklemedikleri bir şeyi gerçekleştirmiş olduğunu ve "hasta adam" olarak vasıflandırılan Türkiye'den güçlü ve kuvvetli bir ülke yarattığını yazmıștır. Börsen gazetesi de Sevr Muahedesini yırtarak, vatanını on sekiz yıl içinde yeniden kuran Atatürk'ün özellikle, "Askerler İlk Hedefiniz Akdeniz'dir" emrini vermesinden sonra, büyük bir enerji ile cumhuriyet rejimini kurmuş olduğundan bahsetmiştir. Cristelig (Cristing) Dagblat gazetesi Atatürk'ü, Türkiye'de harikalar yaratan, milleti için her türlü fedakârlıktan çekinmeyen ve hazırlanan her türlü komployu amansız bir şekilde ezen kişi olarak tanımladıktan sonra şu ifadeyi kullanmıştır; "Kılıç kullanan kol, ancak hâkimiyet asasını elinde tutmaya liyakat kesbeder. Dövizi bozkurtun şiarı olmuştur ${ }^{134,}$.

National Tidence, Atatürk'ü şahsiyet ve kabiliyetin en büyük timsali ve XX. asrın en muazzam olayını yaratan adam olarak tanımlamıștır. Ayrıca; "Filhakika vücuda getirmiş olduğu eser, yarı şarklı olan ve halifenin şahsiyla, dini yegâne bir kuvvet olarak taniyan bir milleti modern, laik ve milli bir devlet haline getirmesidir. Hakikatte şarkın ruhuna kök salmış sembollerin atılmasını ve yeni bir hayat için radikal bir değişmeyi ifade ediyordu. Atatürk'ün dış politikası, tarihte bir timsal numunesi olarak kalacaktır. Dostça anlaşmalarla harici borçlar meselesini düzeltmiş, boğazları tekrar tahkim etmiş, kan dökmeden Hatay davasını halletmiştir. Birçok islahat arasında iş̧iye yeni bir hayat standardl temin etmis ve arkasinda manen ve maddeten kendi izi üzerinde yürüyebilecek kudrette teçhiz edilmiş bir Türkiye bırakmıştır ${ }^{135 "}$ " cümleleriyle Atatürk'ün büyüklüğünü ortaya koymuştur.

Norveç gazeteleri de Atatürk'ün ölüm haberine geniş yer ayırmış, O'nun tercüme-i halini neşretmiş ve yarattığı tarihi eserini büyük övgülerle anlatmışlardır. Dagbladet gazetesi, Türkiye'nin artık "hasta adam" kimliğini tamamıyla tarihe gömdüğünü yazarken bu başarının Atatürk'e ait olduğunu hatırlatmıştır. La Nation Agraire gazetesi ise, yeni Türkiye'yi yaratan liderin

133 "Bütün Dünya Onu Anıyor", Kurun, 16 Kasım 1938, s. 9; "Danimarka Gazeteleri Atatürk ve Eserinden Hayranlıkla Bahsediyor”, Akşam, 16 Kasım 1938, s. 2; Ayın Tarihi, Kasım 1938, s. 181.

134 "Atatürk Vefatı ve Dünya Matbuatı", Cumhuriyet, 16 Kasım 1938, s. 2; "Ulu Şefimize Dünya'nın Hayranlığı”, Tan, 16 Kasım 1938, s. 7; Ayın Tarihi, Kasım 1938, s. 182.

135 "Danimarka Gazeteleri Atatürk ve Eserinden Hayranlıkla Bahsediyor", Akşam, 16 Kasım 1938, s. 2; "Bütün Dünya Onu Anıyor", Kurun, 16 Kasım 1938, s. 9; "Atatürk Vefatı ve Dünya Matbuatı”, Cumhuriyet, 16 Kasım 1938, s. 2; “Ulu Şefimize Dünya'nın Hayranlığı”, Tan, 16 Kasım 1938, s. 7. 
devlet reisleri arasında birincilik vasfını taşıdığını, Le Morgen Bladet gazetesi de Atatürk'ün tarihte memleketinin en büyük adamlarından birisi olduğunu yazmıştır. Morges Handels gazetesi de ondan yeni Türkiye'yi yaratan ve ona emin bir yol çizen kişi olarak bahsetmiştir ${ }^{136}$.

\section{L-Atatürk' ̈̈ Anma Toplantıları}

Büyük lider Atatürk yalnızca 1938 Kasım'ında değil, daha sonraki tarihlerde de dünya liderleri ve dünya basını tarafından minnet ve saygı ile anılmaya devam etmiştir. 1933-39 yılları arasında Ankara'da İngiltere'nin Büyükelçisi olarak bulunan Percy Loraine, Atatürk'ün ölümünün onuncu yıl münasebetiyle BBC'de, 10 Kasım 1948'de, yaptı̆̆ 1 bir konuşmada; “Atatürk'ün ölümü üzerinden koskoca bir 10 yıl geçti... Geçen bunca yıl benim Atatürk ile antlarıma gölge düsüremedi. $O$, öğle bir karaktere sahip insandı ki, cumhurbaşkanı olduktan sonra bile, onun selamlanması için yapılan resmigeçitlerde asla askeri üniformasını giymedi. Daima şık ve temiz sivil elbiselerle, ipekli şapkasını giyerdi. $O$, çarpıcı ve müstesna bir kişiydi. Devrinin zorluklarını ve tehlikelerini hissettiği halde, bilmezlikten gelerek hiçbir şekilde etkilenmemiş bir kişi görünümü veriyordu... Yani o, tabiat tarafından muazzam bir kuvvetle mükâfatlandırılmıştı. Bu özelliklerinden dolayı, ona benzer başka bir kişi bulamadığım gibi onunla karşılaştırabilece ğim başka kişilere de rastlamadım. Kendi mesuliyetleri çok ă̆ırdl ve onları bütünüyle kabul etti. Onlar karşısında yılmadı̆̆ gibi onlardan da korkmadl ve bunları bașkalarına yansıtmadi... Her șeyini kaybeden askeri bir geleneğe sahip gururlu milletinin enerjisini açı̆̆a çıkardl. Onları özgürlüğe kavuşturup, yıpranmış geçmişi tarihe gömerek, gelecek için kapıları sonuna kadar açtı. Atatürk, bunları yaparken halkına karşı inancını daima muhafaza etti... O bir diktatör olsaydı görüşlerini ve prensiplerini kuvvet yoluyla halka kabul ettirip, onlarin milletten tasdik edilmesini isterdi... Eminim ki, eğer Atatürk yaşasaydl, yeni yapılacak olan cumhurbaşkanlığına adaylığını koymayıp sivil hayata çekilip kendisi görevde olmasa bile kurduğu sistemin etkin bir şekilde çalışıp çalışmayacă̆ını izlerdi...”.

“Atatürk'ün dış politikası, barış, dostluk, uzlașma ve savaşa karșı bir garanti üzerine kurulmuştu. Nitekim Rusya ile barıs yapıldı. Yunanistan ile kavga sona erdirildiği gibi yakın ilişkiler içerisine girildi... Mustafa kemal Atatürk'ün çalışmaları, zamanın yıpratıcılı̆̆ına karşı koymuştur. Bu sistem 1939'dan beri ağırlaşan şartlara karşı direnmesini sürdürdüğ̈̈ gibi hala daha sürdürmektedir. Mustafa Kemal Atatürk tarafindan oluşturulan bu sistem, sadece Türkiye'nin kendi istikrarı için değil, aynı zamanda karışık dünya ve mazlum milletler için de bir örnektir. Türkiye, yönetimini bilen, dostlarını tanıyan, ahde vefa gösteren bir ülke olarak metin bir şekilde yolunda yürümektedir. Türkiye, Atatürk gibi bir şahsiyete sahip olmakla şanslı bir ülkedir... Her şeyden önce ona ulaşılması çok zordu. Çünkü sert

136 “Atatürk ve Dünya Matbuatı”, Cumhuriyet, 14 Kasım 1938, s. 7; Ayın Tarihi, Kasım 1938 , s. 184. 
bir kişiydi. Hayatı çetin yerlerde geçmişti. Fakat adaletliydi. Yol ve yöntemini çok iyi biliyordu. Ona zorla iş yapttrılamazdr. Zalim değildi. Onun bütün çabaları Türk milletinin refahı içindi..."137 sözleriyle büyük lider Atatürk'ü yıllar sonra dahi unutamadığını ve unutamayacağını dile getirmiştir.

Amerika Birleşik Devletleri Başkanı John F. Kennedy, Atatürk'ün 25. ölüm yıldönümü dolayısıyla Türkiye'ye gönderdiği mesajında O'nun için şu cümleleri kullanmıştır; "Atatürk adı insana bu yüz yılın büyük insanlarından birinin tarihi başarılarını, Türk halkına ilham veren liderliğini, modern dünyayı ileri görüşlü anlayışını ve bir askeri lider olarak kudret ve yüksek cesaretini hatırlatmaktadır"138.

Aynı şekilde, İngiltere Başbakanı Sir Alexander Douglas Home'un, 25 yıldönümü dolayısıyla verdiği mesajında da şu övgülere rastlanmaktadır; "Atatürk'ün adl bizce hemen hemen 50 yll önce parlak bir Türk askeri kumandanı olarak biliniyor. Barışı takiben ona büyük milli liderler arasında tarihteki daimi yerini kazandıran devletçilik sıfatlarıyla Atatürk tanıdık $k^{139,}$ diyerek onun büyüklüğünü 25 yıl sonra dahi yâd edebilmiştir ${ }^{140}$.

10 Kasım 1986'da, Ankara Üniversitesindeki anma töreninde Dr. Robert Finn, Atatürk hakkında şunları söylemiştir; "Atatürk sizin kahramanınız ve kurtarıcınız. Türk ulusunu kurtarıp Türkiye Cumhuriyetini kuran bir önder olmakla beraber verdiği dersler bütün insanlık âlemini kapsar... Bu dersler, kurduğu Türkiye Cumhuriyeti, hepimiz için bir örnek olmuş ve olmaya devam edecektir. Atatürk ve düşünceleri sadece Türkiye'nin ve Türk gençliğinin değil tüm dünyanındır. Atatürk'ün Türkiye'si, dünyadaki mazlum uluslara bir model olacaktır. $O$ dünyamızda ki bütün ulusların, insanlık ülküsüne yakışan sosyal hayata kavuşacaklarl günü özlemle bekliyordu ${ }^{141 "}$.

${ }^{137}$ Ahmet Özgiray, "Tanıdığım Atatürk", Atatürk Haftası Armağanı, Genelkurmay ATASE Başkanlığı Yayınları, Ankara 1997, s. 87-91.

${ }_{138}$ Yeni Sabah, 10 Kasım 1963, s.1.

139 Yeni Sabah, 10 Kasım 1963, s. 1; Bir gün Ingiltere Büyükelçisi, Ankara pazarında sebze satan köylülere bir tercüman aracıllğıyla, "Mustafa Kemal'e neden böyle boyun eğiyorsunuz?" diye sordu. Genç bir çiftçi hiç tereddüt etmeden; "Çünkü o, bizi bizden daha iyi biliyor, nelere muhtaç olduğumuzu bizden iyi takdir ediyor" cevabını verdi. Bkz. Thomas Ath Vaidis, Bir Yunanlı Gazeteci Gözüyle Atatürk, Çvr. Elanur Bahar, İstanbul, 2002, s. 2.

140 "Dünya Radyoları Atatürk İçin Neşriyat Yaptılar", Tan, 11 Kasım 1938, s. 2.

${ }^{141}$ Kamuran Ardıç, "Atatürk'ün Yarattı̆̆ı Cağdas Türkiye", i. Ü. Atatürk Illkeleri ve Inkılâp Tarihi Enstitüsü Yıllığı, IV, 1989, s. 117; Kentuky Universitesi Psikiyatristi Dr. Arnold Ludwing, son 100 yıl içinde dünyadaki 377 lider arasında yaptığı, on sekiz yıl süren ilginç çalışmasının sonucunda, büyük önder Mustafa Kemal Atatürk, dünya liderleri arasında en yüksek puanı alarak birinci olmuştur. Dr.Ludwing "Siyasi Büyüklük Cetveli" adını verdiği bu anketi liderlere uygulamıştır. Liderlere, ülke yaratma ve özgürlüğe kavuşturma, savaş kazanma, ülke topraklarını genişletme, ekonomiyi geliştirme, orijinal ideolojiyi yayma, iktidarda kalma süresi ve ahlaki değer ve başarılarını baz alarak puan verilmiş, 37 puan üzerinden yapılan değerlendirmede Atatürk 31 puan alarak listenin en üstünde yer almıstır. Atatürk'ü 30 puanla ABD Başkanı Franklin D.Roosevelt ile Çin lideri Mao izlemiştir. Diğer önderler ise sırasıyla 29 puanla Stalin, 26 puanla Mussolini ve 25 puanla Hitler takip etmiştir. Sıralama arasında Atatürk'ün çağdașı olarak yer alan Hitler, Stalin ve Mussolini çoktan tarih olup reddedildikleri halde, açıkçası Atatürk düşünceleri ile bu gün hala yaşamakta ve insanlığa ışık tutmaktadır. 


\section{SONUÇ}

Atatürk'ün gerçekleştirdiği inkılâp ve ilkeleri O'nun düşünce gücü ve fikri yapısının sağlamlığının bir göstergesidir. O'nun zamanında ortaya çıkan liderlerin birçoğunun isimleri günümüzde unutulmuş olduğu halde Atatürk, fikirleri ve inkılâpları ile ülkesinin ve milletinin yolunu aydınlatmaya devam etmektedir. Milleti için yarattığı yeni Türkiye, bütün insanlık âlemini de etkilemiş ve onun manevi varlığını evrensel boyutlara ulaştırmıştır. Kısaca sömürge altında ki ülkelerin bağımsızlık yolunu aydınlatan 1şık Türk İnkılâbı olmuştur. Bu inkılâp, özgürlüğü kazanmanın ancak akıllcı, bilinçli ve disiplinli bir çalışmayla olabileceğini açık bir biçimde göstermiştir. Böylece dünya emperyalizmine yön veren devletin devlet adamlarına, "Yüzylllar ender olarak dahi yetiştirir, şu talihsizliğimize bakın ki bu yüzyılın dâhisi Türklere nasip oldu" sözünü söyletebilmiştir.

Fikir ve düşünceleriyle yaşadığımız çağın en büyük lideri olan Atatürk, onun içindir ki, doğumunun 100. yılında uluslararası anma törenlerinde ele alınmış ve hemen her devlet tarafından ismi saygıyla anılmıştır. Birleşmiş Milletler Teşkilatı'nın öncülüğünde çeşitli ülkelerde fikir ve düşünceleri işlenmiş, kitaplar yazılmış ve O'nun adıyla birlikte Türk milleti de yücelmiștir. Bu suretle ölümü üzerinden geçen her y1l onu daha da ölümsüzleştirmiştir. Atatürk'ü evrenselleştiren en önemli yanı, onun insan sevgisi ve insanlık ülküsü olmuştur. Atatürk, dünya insanlığını bir bütün olarak kabul edip, Türk milletinin varlığı ve mutluluğu kadar bütün dünya milletlerinin de barış içinde mutluluğuna hizmet etmeye elinden geldiği kadar çalışmıștır. Bu açıdan Atatürk, bütün yönleriyle geçmişte olduğu gibi çağdaş yazarlar ve düşünürler tarafından hala incelenmekte ve değerlendirilmektedir. Atatürk, yarattığı siyasal, kültürel ve sosyal inkılâplarla Türk tarihinin ve dünya tarihinin akışını değiştiren ve ona yeni bir yön veren, insanlığın seçkin evladı durumuna yükselmiştir.

İngiltere, ölümünden sonra Atatürk için yorum yaparken O'nu cevval, cesur bir düşman sonra da sadık bir dost olarak tanımlamış, yalnız Türkiye'nin bütün hayatını değiştiren bir deha değil, devlet adamlarının en cesur ve en orijinali olarak değerlendirmiştir. $\mathrm{O}$, kendileri için sağlam bir Şark politikasının esasını kuran bir devlet adamı olmanın yanı sıra, Avrupa'nın Türkler için kullandığı "Hasta Adam" tabirini değiştiren ve Avrupa otoritelerini mahcup eden bir lider olmuştur. Aynı zamanda ülkesinde savaştan sonra büyük bir atılım gerçekleştirmiş, yıllarca süren savaşlar yüzünden geri kalmış olan Türk tarımını modern usullerle yeniden başlatmış, kadını ve erkeği ile Türk insanını içinde bulunduğu dar ortamdan çıkararak çağdaş bir seviyeye ulaştırmış gerçek bir devlet adamı olmuştur. Medeniyet sahasında Batının çağdaş medeniyet seviyesini hedeflemiş olması bütün batı dünyasını son derece etkilemiştir. Türkleri kendilerine düşman olarak gördükleri halde ve Atatürk'ün bu bakış açısını bilmesine rağmen 
yine de Avrupa'ya yönelmesini büyük bir takdirle karşıladıklarını yazmışlardır.

İngiltere özellikle onun insani yönü üzerinde durmuş ve batılı devletlerle dostluk ilişkisi içerisinde bulunmasını takdir etmiştir. Dış politikada gerçekleştirdiği faaliyetlerle Türkiye, Avrupa'nın politik hayatının kıymetli ve müterakki bir azası haline gelmişti. Bütün bu gelişmeleri büyük bir hayranlıkla karşılayan İngiltere, bu kadar büyük bir başarıyı Avrupa'nın liderlerinden hiç birisinin gerçekleştiremediğini çünkü onların Atatürk'ün karşılaştığı zorlukların daha büyüğüne maruz kalmadıklarını da vurgulamışlardır. Yaptıkları yorumlara göre, onun başarıları Türkiye'yi bir Avrupa devleti yapmış ve Yakın Doğu'nun tarihini değiştirmiştir. Memleket endüstrisini kurmak için geniş projeler hazırlamış olması, memleket kaynaklarının geniş ölçüde işletilmesi, milli enerjiyi canlandırması, sosyal hayatı hızlı bir şekilde değiştirmesi, Türkiye’ye mazi gözüyle bakanların imkânsız saydıkları işi başarması çok büyük övgülerle özellikle vurgulanmıştır.

Bir milletin bu derece değişmesi tarihte gerçekte eşi olmayan bir hadise olarak kabul edilmiş, onun dünya barışına yaptığı katkıyı hürmetle anarken, yeni bir Türkiye yaratmak için verdiği mücadeleyi de büyük bir saygı ile kabul etmişlerdir. Hatta Atatürk'ün Türkiye'yi hesaba katılması gereken yeni bir memleket haline getirmesinden de bahsederek, hasta adam unvanından da kurtulduğunu yazmışlardır.

Fransa için Atatürk laikliği gerçekleştiren büyük bir lider; ülkesini şarklılık damgasından tamamen kurtarmayı başaran barışçı bir devlet adamıdı. Atatürk sonuçta büyük bir medeniyet eseri meydana getirmiş ve el koyduğu her şeyde tamamıyla başarılı olmuştu. O, aynı zamanda Fransa için, olayları değerlendirmede üstün yeteneklere sahip bir insan, hoş sohbet, etkileyici, insanları ikna edici, fikirlerinde idealist, hayallerinin, onlara çizdiği hudutları aşmasına müsaade etmeyen karaktere sahip bir kişiydi. Ankara'da imzalanan Türk-Fransız Antlaşmasını ön plana çıkaran Fransız gazeteleri, ondan geriye kalan bağımsız ve müstakil Türkiye'nin, kuvvetli ve modern bir ordunun Türk milleti için en büyük bir güvence olduğunu vurgulamışlardır. Bütün bu reform hareketleriyle, Balkan Antantı'nın lideri ve Şark paktının yaratıcısı olan Türkiye, dünyada kendi mevkisini almıştı. Bundan dolayı da Atatürk'ün şöhretinin memleketten memlekete geçerek hayatının efsanevi denebilecek bir mahiyet aldığını dahi belirtmişlerdir.

Almanya için Atatürk zamanın objektif zihniyetli ve temkinli büyük bir barış mimarı ve yüzyılın en büyük devlet adamı, Doğu Avrupa'da yükselen bir uygarlık abidesiydi. Atatürk'ün dünya barışı yolundaki çabaları hiç kuşkusuz yabancı devlet adamlarını ve bilim dünyasını etkileyen en önemli yanı olmuştur. $O$, ülkesinin gerçek sahibi olarak tanımladığı köylüyü yüceltmekle kalmamış, ona bilgi, insanlık, Türklük şerefi kazandırmıştı. O, milletini, asırlık uykusundan uyandırarak, on sene içerisinde Türkiye'yi beş, 
altı asır ileri götürmüştü. Aynı zamanda yenilmez bir iradeye sahip, iyi kalpli, insan bir adamdı. Özellikle Fransızların ve İngilizlerin rolüne de değinen Alman gazeteleri büyük liderin üstün vasıfları karşısında mağlup olduklarını söylemiştir. Kısaca belirtilen ana fikir, Almanya'nın Atatürk'ün eserine ve mücadelesine hayran olduğu fikridir. Hatta böyle büyük bir adamın bir daha dünyaya geleceğini zannetmediklerini dahi söylemişlerdir. O gerçek anlamda yeni Türkiye'nin yaratıcısı ve kurucusu olmuş, bütün dünya'nın hayran kaldığı bir kalkınmayı gerçekleştirmiş, Yakın Doğu'nun şimdiki çehresini tespit etmiştir.

Atatürk'ün başarısının istiklal hissini taşıyan bütün milletler için ölmez bir sembol olduğundan bahisle, eski düşmanlarıyla barış yaparak onlarla dost olacak kadar büyük bir insan olduğunu da vurgulamışlardır. Atatürk'ün, ülkesinde ve dünyada adil ve takdir edilen bir mevki kazanmasını da takip ettiği bu politikaya dayandıran Alman gazeteleri ayrıca kendi milletine ruh aşılamasını da belirterek tekrar cihan politikasının orta noktasında yer almış olmasını büyük bir başarı olarak kabul etmişlerdir.

Dikkat çeken bir başka husus da onun ülkesine olan sevgisi dolayısıyla milletine ne kadar büyük hizmetlerde bulunduğunun vurgulanmış olmasıdır. Milletinin unutulan tarihinin yeniden araştırılması için bir heyet oluşturması ve Türkçe'nin, Arapça ve Farsça'nın etkisinden kurtarılarak Türk dilinin mükemmel ve muntazam bir milli dil haline getirilmesi onun en büyük başarısı şeklinde algılanmıştır. Yaptırttığı araştırmalarda Türk tarihini İslamiyet'ten önceki dönemlere kadar götüren bilgileri gün 1şığına çıkarmıştır. Bu yönüyle Atatürk, büyük bir öğretmen olarak vurgulanmış buna örnek olarak da onun yazdırdığı dört ciltlik Türk Tarihi kitabı gösterilmiştir. Bu yönde yapılan yorumlarda, dünyanın hiçbir yerinde Türkiye'nin karşılaştığı pedagojik meselelerden daha büyüğü olmadığg ve hiçbir yerinde de hiç kimsenin bu hususta Atatürk'ten daha kati ve cesur teşebbüslere girişilmemiş olduğu belirtilmiştir. Böylece Avrupa'nın Türk Tarihi hakkındaki düşüncesini yıktığı da açıkça ortaya konulmuştur.

O yalnızca Türk milleti için değil bütün mazlum milletler için de bir ışık kaynağı olmuştu. Şöyle ki Doğu milletlerinin, barış içinde yaşamalarıyla birlikte ilerlemelerinin de Atatürk sayesinde sağlandığı belirtilmiştir. Göze çarpan bir başka husus da onun kimliğinin Nil sahillerinden Çin Denizlerine kadar uzanan bir efsane olduğunu, Türkiye'nin Atatürk'ün idaresi altında yeniden Yakın-Şark'ta bir anahtar görevini üstlendiğini, siyasi sahada ise Doğu Avrupa'da denge sağladığını ve dünyanın bu kısmında yaşayan milletlerin bağımsızlıklarını muhafaza edeceğini de vurgulamışlardır.

Çekoslovakya onu yeni Türkiye'ye ruh veren adam olarak algılayıp böylesine yüksek derecede bir lidere sahip olduklarından dolayı da Türklere gıpta ettiklerini açıkça ifade ederek kendilerinin Mustafa Kemal'in dünya sahnesinde göründüğü zamandaki Türkiye'nin vaziyetine benzer bir mevkide bulunduklarını söylemişlerdir. Kendisini demirden iradenin timsali olarak algılayıp memleketine yeni bir anayasa, yeni bir kültür, yeni bir ülkü 
verdiğini, memleketinde kuvvetli bir sanayi yaratarak Müslümanlık âleminde bir mucize yarattığını da belirtmişlerdir Böylece Atatürk'ü büyük bir medeniyet kaynağı olarak kabul edip, onun Türkiye'yi batılılaştırmaktan ziyade, milletin müdafaası, geleceği ve ilerlemesi için ona hayat olarak gerekli olan unsurları vermek istediğini ifade etmişlerdir. Son olarak onun, Türkiye'yi batı ile doğu arasında bir köprü durumuna getirerek, bu politika sayesinde hiç kimsenin artık Türkiye'ye saldırmaya cesaret edemeyeceğini vurgulamış olmaları da dikkat çekicidir.

\section{KAYNAKÇA}

Akşam, Kasım 1938.

Ayın Tarihi, Kasım 1938, S. 60.

Cumhuriyet, Kasım 1938.

Kurun, Kasım 1938.

Tan, Kasım 1938.

Ulus, Kasım 1938.

Yeni Sabah, Kasım 1938.

Avc1, Cemal, "Türkiye ve Dünya için Artarak Devam Eden Önemi ile Atatürkçü Düşünce Sistemi", Beşinci Uluslararası Atatürk Kongresi, I, Ankara 2005, s. 843-848.

Baycu, Turhan, "Yabancı Gözüyle Atatürk", Atatürk Araştırma Merkezi Dergisi, III, Mart 1987, S. 8, s. 393-399.

İlgazi, Abdullah, "Dün Bugün ve Gelecekte ki Yansımalarıyla Atatürk'ün İnsan Haklarına Verdiği Değer”, 4. Uluslararası Atatürk Kongresi, I, s. 419-429.

Kamuran Ardıç, “Atatürk'ün Yarattığı Çağdaş Türkiye”, İ.Ü. Atatürk Illkeleri ve Inkılâp Tarihi Enstitüsü Yıllığı, IV, 1989, s. 117.

Kaşgarlı, Mehlika Aktok, "Kurtuluş Savaşında Türk-Fransız İlişkileri ve Mustafa Kemal Atatürk’ü En İyi Anlayan ve Tanıyan Fransız Devlet Adamı Adouard Herriot", 4. Uluslararası Atatürk Kongresi, I, Ankara, 2000, s.191-196.

Özgiray, Ahmet, "Tanıdığım Atatürk”, Atatürk Haftası Armağanı, Genelkurmay ATASE Başkanlığı Yayınları, Ankara, 1997, s.87-92.

Sonyel, Salahi R., "Yabancı Kaynaklara Göre Kurtuluş Savaşı Döneminde Mustafa Kemal Atatürk'ün Evrenselliği”, Üçüncü Uluslararası Atatürk Sempozyumu, I, Ankara, 1998, s. 35-54.

Sonyel, Salahi R., "Yabancı Gözü ile Atatürk", Türk Kültürü, IX, No. 91, Kasım 1970, s. 24-25. 
Sonyel, Salahi R., "Büyük General, Asil Düşman ve Cömert Dost Gazi Mustafa Kemal”, Belleten, XLIII, No.171, Temmuz 1979; s. 75.

Şimşir, Bilal, “Atatürk’ün Küresel Yönü Üzerine Şematik Bir Bakış” , Beşinci Uluslararasi Atatürk Kongresi, I, Ankara, 2005, s. 135-148.

Vaidis, Thomas Ath, Bir Yunanlt Gazeteci Gözüyle Atatürk, Çev.: Elanur Bahar, İstanbul, 2002.

Yabancı Gözüyle Cumhuriyet Türkiyesi (1923-1938), İstanbul, 2003.

Yılmaz, Mustafa, "İngiliz Büyükelçiliği Yıllık Raporlarında Türkiye (1935-1938)”, Beşinci Uluslar Arası Atatürk Kongresi, I, Ankara 2005, s. 635-646. 